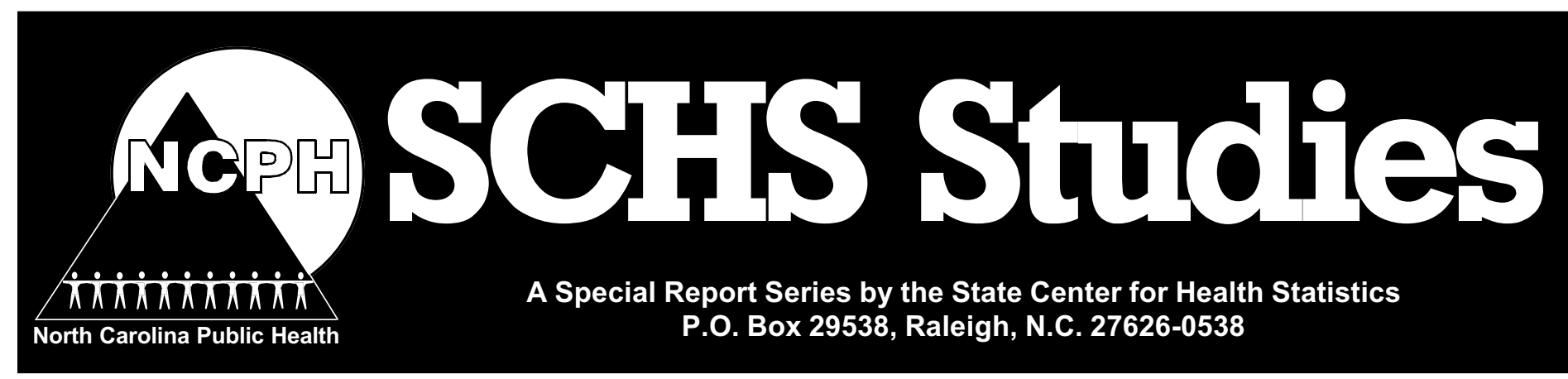

No. 106

May 1997

\title{
NORTH CAROLINA'S HEALTH REPORT CARD: PROGRESS TOWARD THE HEALTHY PEOPLE 2000 OBJECTIVES
}

\author{
By
}

Kathryn B. McLawhorn

\begin{abstract}
The national Healthy People 2000 program provides guidance and direction for improving the health of all citizens. The Year 2000 objectives were established in 1987 by the United States Public Health Service and are published in Healthy People 2000: National Health Promotion and Disease Prevention Objectives. The three primary goals of Healthy People 2000 are to increase Americans' span of healthy life, to reduce health disparities among Americans, and to achieve access to preventive services for all Americans.

This report charts North Carolina's progress toward achieving the Year 2000 objectives. A subset of 70 objectives from the 22 Year 2000 priority areas was examined over the time period 1990-1995. Trends in these objectives were compared to the national Year 2000 targets to assess improvements in health status and areas of concern.

The results of this report reveal the following about North Carolina's progress toward the Healthy People 2000 objectives: the state has currently achieved 11 of the objectives; we are moving in the right direction on 32 of the objectives; and we are moving in the wrong direction on 19 of the objectives. For eight of the objectives, there was baseline data but no current data to track progress. North Carolina has made significant progress, but improvements must continue in reducing disease and promoting healthy lifestyles.

This report revealed many areas for which there are few, if any, reliable sources of data for tracking progress on objectives. It concludes by examining the data gaps in detail and suggesting where resources and attention might be directed for more complete data collection.
\end{abstract}




\section{INTRODUCTION}

In 1987, the National Academy of Sciences Institute of Medicine and the United States Public Health Service expanded upon previous efforts to develop strategies for health promotion and disease prevention. A task force of health care providers, researchers, organizations, and individuals was convened to develop objectives for the nation. The resulting objectives were published in the report Healthy People 2000: National Health Promotion and Disease Prevention Objectives.

The objectives address areas such as improvements in health status, risk reduction, prevention awareness, and surveillance and evaluation. Emphasis was placed on prevention of disability and morbidity, improvements in the health status of high risk population groups, and screening interventions. The objectives were divided into 22 priority areas listed below:

Physical Activity and Fitness

Nutrition

Tobacco

Substance Abuse: Alcohol and Other Drugs

Family Planning

Mental Health and Mental Disorders

Violent and Abusive Behavior

Educational and Community-Based Programs

Unintentional Injuries

Occupational Safety and Health

Environmental Health

Food and Drug Safety

Oral Health

Maternal and Infant Health

Heart Disease and Stroke

Cancer

Diabetes and Chronic Disabling Conditions

HIV Infection

Sexually Transmitted Diseases

Immunization and Infectious Diseases

Clinical Preventive Services

Surveillance and Data Systems
This report uses a small, but key, subset of the objectives for which North Carolina has consistent, reliable, and accessible data to assess this state's progress toward achieving the Year 2000 objectives.* This study concludes by highlighting areas where North Carolina lacks sufficient data to evaluate progress. There is a companion SCHS Studies report (\#102) on the Year 2000 Child Health Objectives (Waller, 1997).

\section{METHODS}

The data used to compile this report was drawn from a variety of resources. Much of the information related to deaths, births, hospitalizations, and communicable diseases is found in the statistical files housed at the State Center for Health Statistics. The mortality rates that require age-adjustment are adjusted to the 1940 U. S. Census population using the direct method.

Data on physical activity, overweight status, tobacco use, diabetes prevalence, screening for cholesterol and high blood pressure, and mammogram and pap smear use come from the Behavioral Risk Factor Surveillance System (BRFSS). This ongoing, monthly telephone survey is conducted by the Office of Epidemiology, Division of Health Promotion, Department of Environment, Health, and Natural Resources (DEHNR) using a random sample of the North Carolina population ages 18 and older. BRFSS results are weighted to account for the age, race, and sex distribution of the state's population. Data may not be available for each year since some questions were not included in the survey every year.

During inter-censal years, population data is provided only for total, whites, and minorities. Population-based rates for the black population are included in this study, where applicable, only for census year 1990 when a breakdown of the minority population was available.

\footnotetext{
*A complete database for Year 2000 objectives for which North Carolina has reliable, accessible data can be found on the Internet at
} http://hermes.sches.ehnr.state.nc.us/intra/. 
Other types and sources of data used in this report:

- Substance abuse data specific to grades 9 through 12 is provided by the Youth Risk Behavior Survey. The Department of Public Instruction began collecting this data in 1990 and conducted additional surveys in 1993 and 1995.

- The Department of Labor's Research and Statistics Division provided information on workrelated injuries and fatalities. These rates are based on data for persons employed full-time.

- Immunization data for children was provided by the Immunization Section of DEHNR's Division of Maternal and Child Health. In addition, the BRFSS includes questions on immunizations among adults ages 65 and older.

- The information on access to care and financial barriers was provided through the North Carolina Health Profile Survey. This survey was conducted in 1994 by the State Center for Health Statistics.
Appendix A shows the Healthy People 2000 objectives contained in this report. It shows the baseline and current data for North Carolina for each objective, and the state's progress toward the Year 2000 goal.

\section{RESULTS}

\section{Physical Activity and Fitness}

Physical activity can reduce the risk of many diseases, such as heart disease and cancer, and promote a healthy lifestyle. One of the challenges of the national Healthy People 2000 Program is to move society from sedentary behavior to a more physically active lifestyle.

Figure 1 shows a high percentage of no leisure-time physical activity among all population groups in North Carolina. In fact, the trend indicates that the state is moving away from this Year 2000 goal. For example, in $1990,40.3$ percent of the population ages 18 and older engaged in no leisure-time physical activity. By

\section{Figure 1}

Objective 1.5:

Percentage of people who engage in no leisure-time physical activity: North Carolina, 1990-1994

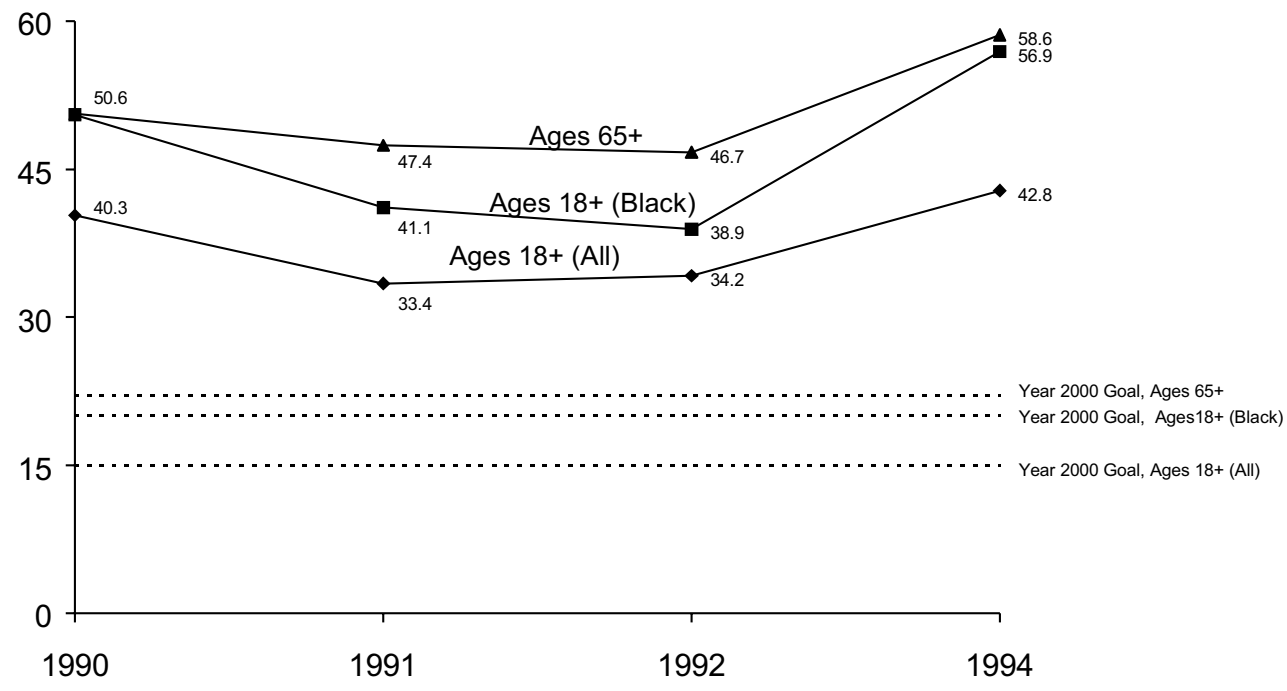

Source: Behavioral Risk Factor Surveillance System, Division of Health Promotion 
1994, that percentage increased to 42.8 , while the national goal recommends that no more than 15 percent of the population should be sedentary.

Since 1990, North Carolina has shown some improvement in the percentage of adults who engage in vigorous physical activity (Figure 2). The Year 2000 goal for people of all races ages 18 and older is 20 percent, while the goal for blacks ages 18 and older is 17 percent. By 1994, those percentages were 9.3 and 6.2 , respectively.

\section{Nutrition}

The proportion of the population that is overweight is increasing for North Carolinians, as well as for all Americans (Midcourse Review, 1995). Figure 3 shows trends that are increasing away from the Year 2000 goals. This is a particular concern among special population groups such as low income women and black women. Despite a goal of 20 percent, the overall prevalence of obesity for people ages 20 and older rose from 25.2 to 29.3 percent between 1990 and 1995.
Healthy dietary practices are important for reducing the pattern of obesity. Knowledge of dietary fat and cholesterol can help people to make healthy food choices. The proportion of North Carolinians who have had their blood cholesterol checked is moving in the right direction toward the national goal of 75 percent (Figure 4). In 1990, 64.8 percent of the population had received a cholesterol screening in their lifetime compared to 68.5 percent in 1995.

\section{Tobacco}

Smoking and the use of tobacco products contribute to over 400,000 deaths each year in the United States and cause increased risk of disease (MMWR, 1993). Cigarette smoking among people ages 18 and older in North Carolina is decreasing (Table 1). In 1990, 28.5 percent of adults reported smoking; by 1995 , the proportion decreased to 25.8 percent. In addition, in 1995, 48.3 percent of smokers ages 18 and older reported that they had stopped smoking cigarettes for at least one day during the preceding year,

\section{Figure 2}

Objective 1.4:

Percentage of people who engage in vigorous physical activity:

North Carolina, 1990-1994

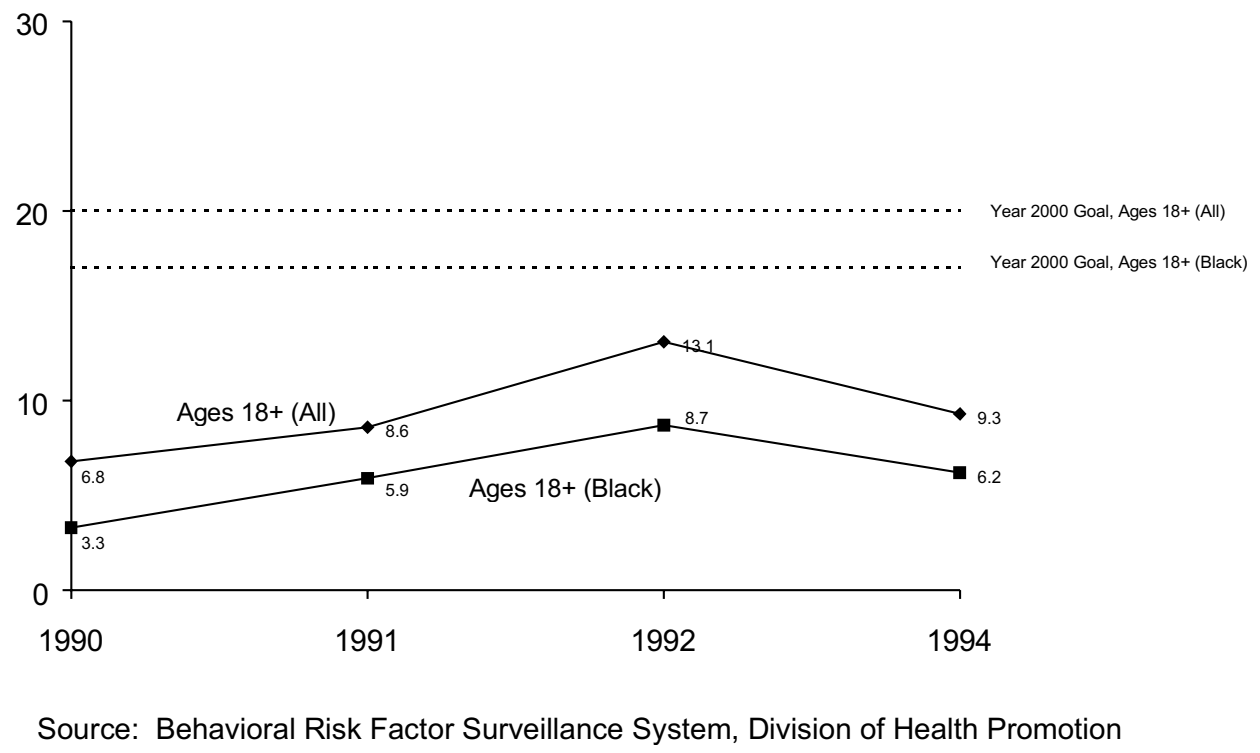




\section{Figure 3}

Objective 2.3:

Percentage of people who are overweight (based on body mass index*):

North Carolina, 1990-1995

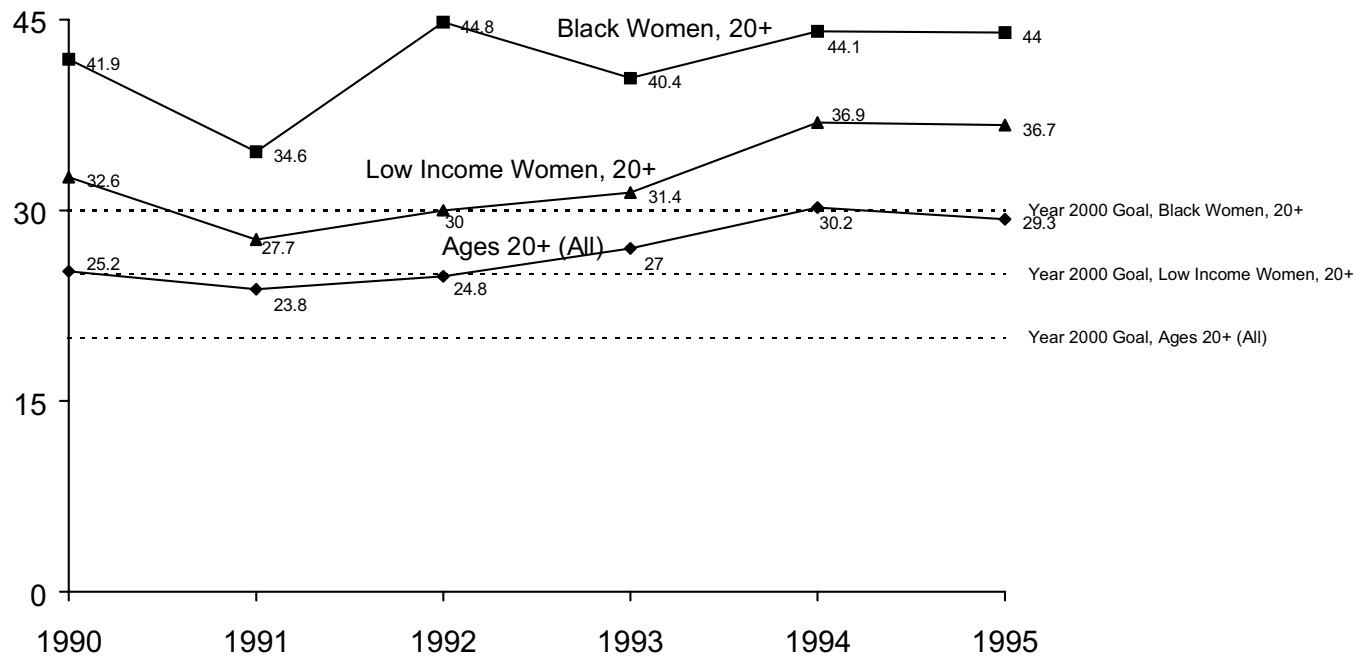

${ }^{*} \mathrm{BMI}=$ weight divided by height squared $(\mathrm{kg} / \mathrm{m} 2)$; overweight if men $>=27.8$; women $>=27.3$

Source: Behavioral Risk Factor Surveillance System, Division of Health Promotion

\section{Figure 4}

Objective 21.2:

Percentage of people who have had their blood cholesterol checked:

North Carolina, 1990-1995

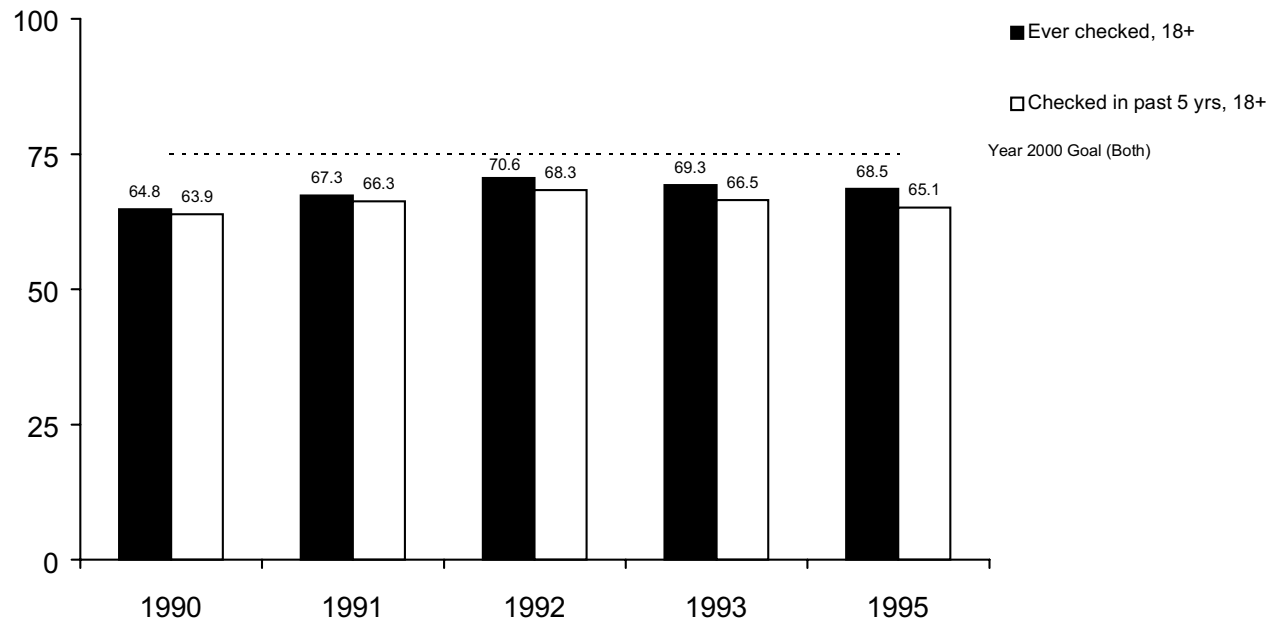

Source: Behavioral Risk Factor Surveillance System, Division of Health Promotion 


\begin{tabular}{|c|c|c|c|c|c|c|c|}
\hline \multicolumn{8}{|c|}{ Table 1} \\
\hline \multirow[b]{2}{*}{ Objective } & \multicolumn{6}{|c|}{ North Carolina Percentages } & \multirow{2}{*}{$\begin{array}{c}\text { Year } \\
2000 \text { Goal }\end{array}$} \\
\hline & 1990 & 1991 & 1992 & 1993 & 1994 & 1995 & \\
\hline $\begin{array}{l}\text { 3.4 Cigarette smoking prevalence, } \\
\text { ages } 18+\end{array}$ & 28.5 & 24.4 & 26.7 & 25.8 & 27.7 & 25.8 & 15.0 \\
\hline $\begin{array}{l}\text { 4.6 Cigarette use in past month, } \\
\text { grades } 9-12\end{array}$ & 32.0 & - & - & 29.0 & - & 31.0 & 6.0 \\
\hline $\begin{array}{l}\text { 3.6 Smoking cessation for at } \\
\text { least one day, ages } 18+\end{array}$ & - & - & - & - & 42.9 & 48.3 & 50.0 \\
\hline $\begin{aligned} \text { Source: } & \text { Behavioral Risk Factor Surveill } \\
& \text { Youth Risk Behavior Survey, De }\end{aligned}$ & $\begin{array}{l}\text { em, } \\
\text { of } \mathrm{Pu}\end{array}$ & sion & ion & motic & & & \\
\hline
\end{tabular}

up from 42.9 percent in 1994. The Year 2000 goal 50 percent of current smokers quit for at least one day - is attainable if this trend continues.

Tobacco use by young people is a special concern in the state and the nation. The decline among 9th through 12th graders is small, and tobacco use by North Carolina's youth is still significantly higher than the Year 2000 goal of six percent (Table 1).

\section{Substance Abuse: Alcohol and Other Drugs}

Reducing the detrimental effects of alcohol and other drugs is another priority area for the Year 2000. In the early 1990's, drug-related deaths were already below the Year 2000 goal of 3.0 per 100,000 population; but in 1995, that rate increased to 3.2, slightly above the goal (Figure 5). Cirrhosis is a chronic liver disease often associated with alcohol abuse. Death rates from this disease indicate improving trends for the state.

As with tobacco, substance abuse is a special concern in the state and nation. Table 2 shows that for grades 9 through 12, reported alcohol and marijuana use in the previous month both increased between 1990 and 1995, with marijuana use showing the largest increase, from 16.0 to 21.7 percent, and the widest gap between the 1995 figure and the Year 2000 objective.

\section{Family Planning}

Teen pregnancy and adolescent sexual behavior are emphasized in the Family Planning priority area. The teen pregnancy rate for females ages 15-17 decreased from 71.7 to 65.1 per 1,000 population between 1990 and 1995 (Figure 6). Considerable improvement, however, is required to reach the Year 2000 goal of 50.0 pregnancies per 1,000 adolescents. For additional information related to this area, see the companion SCHS Studies report \#102 (Waller, 1997) on child health objectives.

\section{Mental Health and Mental Disorders}

While the suicide rate for the total population in North Carolina is declining, the suicide rate among adolescents ages 15-19 is increasing (Figure 7). Between 1990 and 1995, the suicide rate for this age group increased from 10.5 to 13.8 deaths per 100,000 population. Based on current trends, the rates will not reach the Year 2000 goal of no more than 8.2 suicides per 100,000 adolescents ages 15-19. 


\section{Figure 5}

Objectives 4.2,4.3:

Cirrhosis and Drug-related death rates, age-adjusted per 100,000 population:

North Carolina, 1990-1995

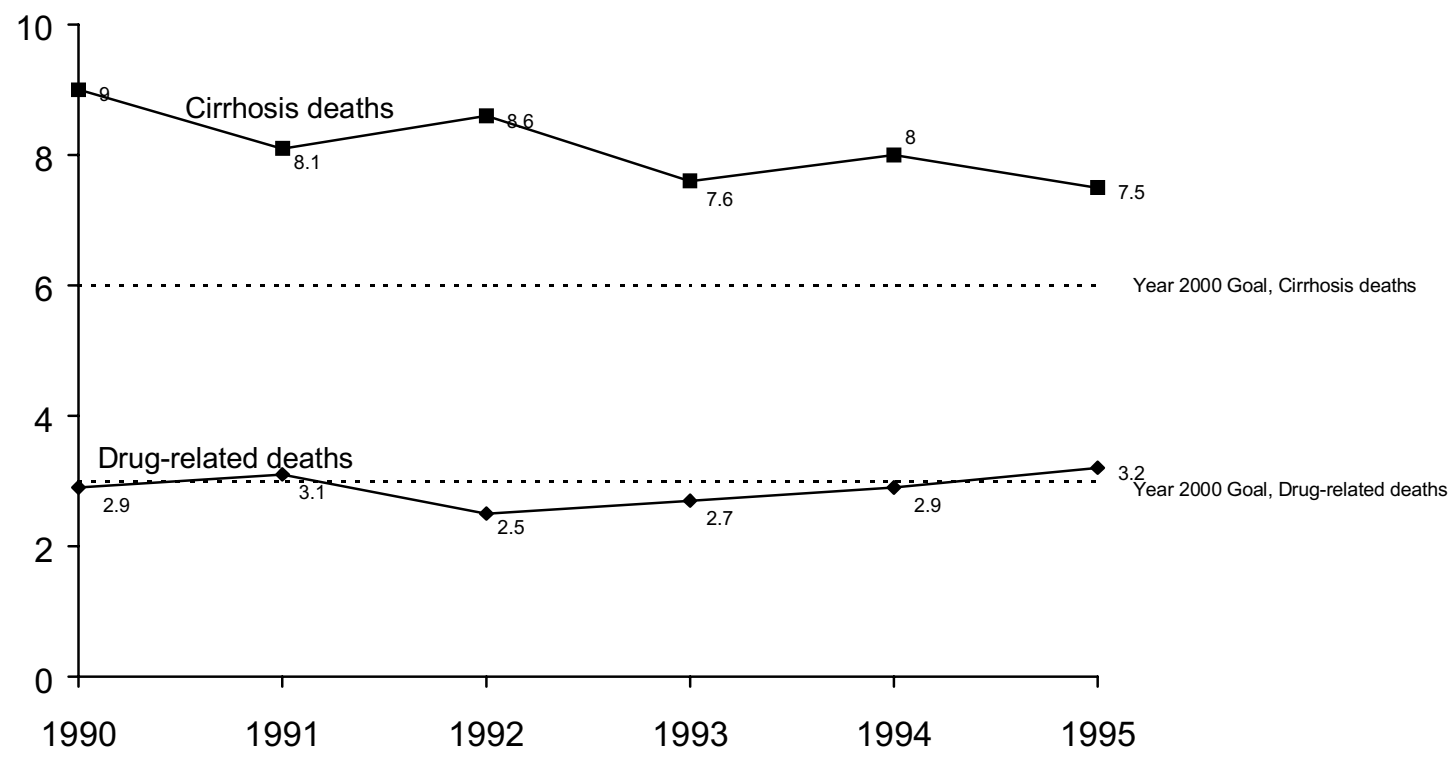

Source: State Center for Health Statistics

Table 2

\begin{tabular}{|c|c|c|c|c|}
\hline \multirow[b]{2}{*}{ Objective } & \multicolumn{3}{|c|}{ North Carolina Percentages } & \multirow{2}{*}{$\begin{array}{c}\text { Year } \\
2000 \text { Goal }\end{array}$} \\
\hline & 1990 & 1993 & 1995 & \\
\hline 4.6 Alcohol use in past month, grades 9-12 & 35.0 & 44.0 & 39.7 & 12.6 \\
\hline 4.6 Marijuana use in past month, grades $9-12$ & 16.0 & 15.0 & 21.7 & 3.2 \\
\hline
\end{tabular}




\section{Figure 6}

Objective 5.1:

Teen pregnancy rates, per 1,000 population:

North Carolina, 1990-1995

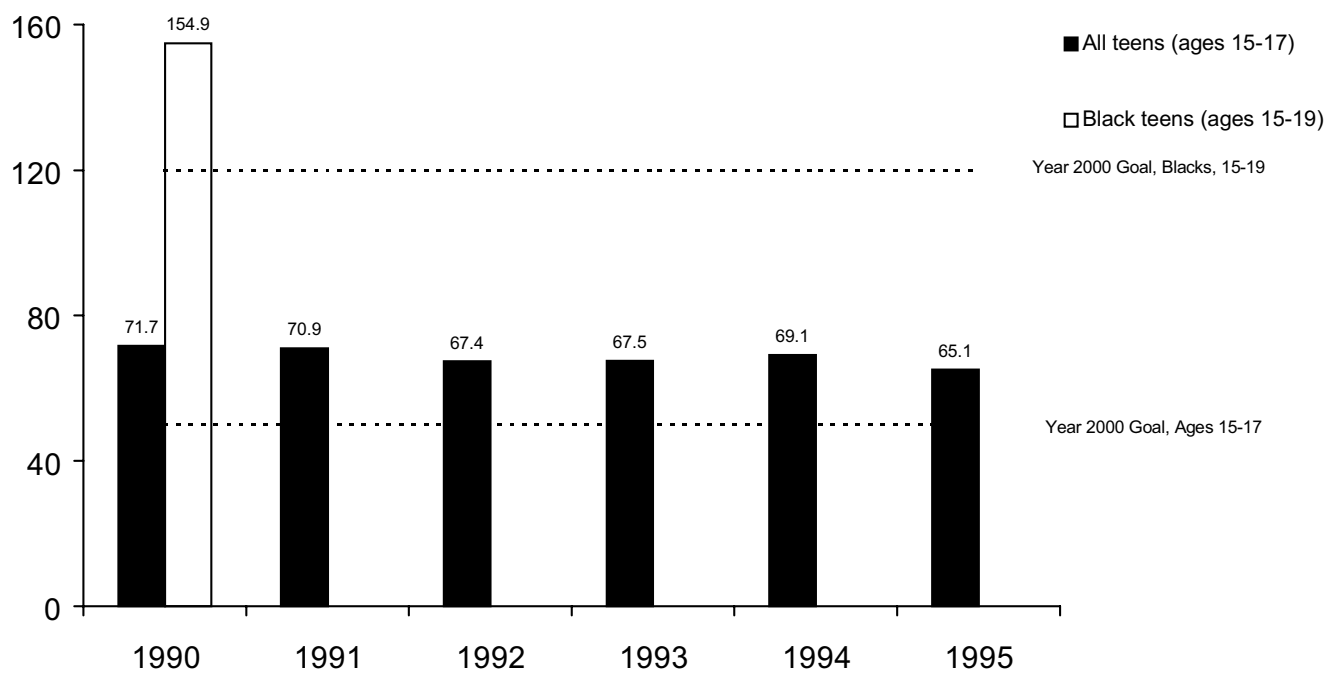

Source: State Center for Health Statistics

\section{Figure 7}

Objective 6.1:

Suicide death rates, per 100,000 population:

North Carolina, 1990-1995

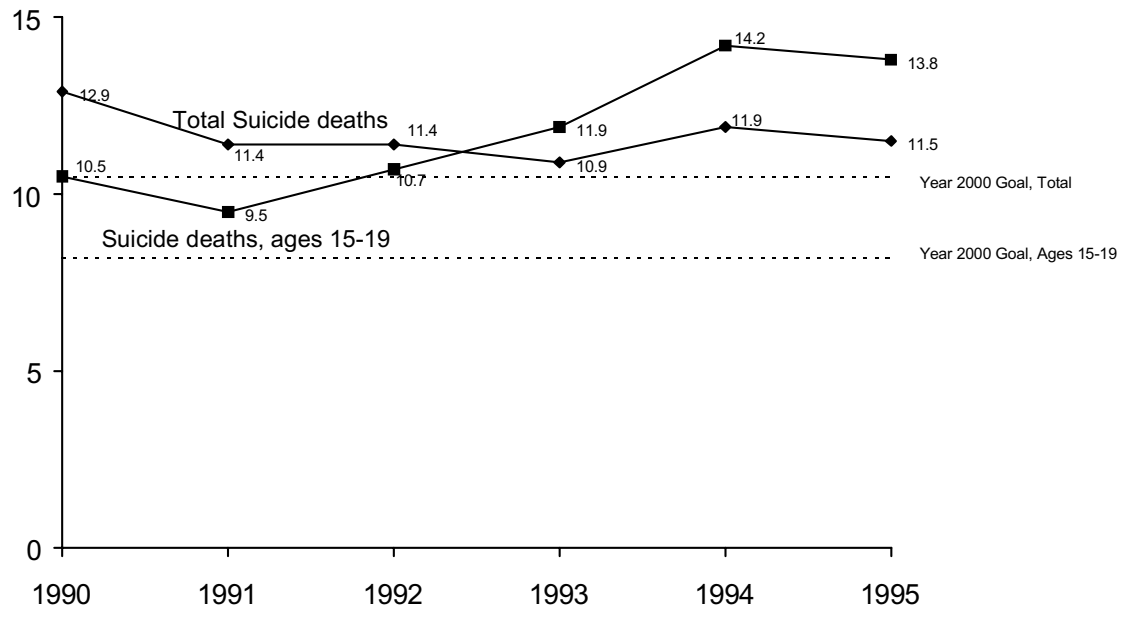

Source: State Center for Health Statistics 


\section{Violent and Abusive Behavior}

Violence is one of the greatest threats to public health and social well-being today. The total homicide death rate in North Carolina is moving in the right direction toward the national goal of 7.2 per 100,000 population (Figure 8). In 1990 in North Carolina, the homicide death rate for black males ages 15-34 was moderately above the Year 2000 goal of 72.4. National data indicates that the homicide rate for black males ages 15-34 is currently almost twice the Year 2000 goal of 72.4 per 100,000 (Review 1995-96, 1996).

\section{Unintentional Injuries}

The Unintentional Injuries priority area includes objectives for injury deaths, injury-related hospitalizations, and motor vehicle safety. Death rates for both unintentional injuries and motor vehicle crashes decreased between 1990 and 1995 (Figure 9).

The hospitalization rate for non-fatal, unintentional injuries (Figure 10) improved from 885.6 discharges per 100,000 population in 1990 to 819.5 in
1993. The hospitalization rate for head injuries has been consistently below the Year 2000 goal of 106.0 since 1990, with a rate of 80.4 per 100,000 in 1993. Hip fracture hospitalizations for people ages 65 and older, however, show an increasing trend. In contrast to the national goal of 607.0, the North Carolina rate rose from 712.4 in 1990 to 735.4 per 100,000 in 1993.

\section{Occupational Safety and Health}

Promoting safe and healthy workplaces free of diseases, injuries, and deaths is another challenge for the Year 2000. The death rate for overall work-related injuries increased 24.5 percent from 1992 to 1994 (Figure 11). Transportation workers experienced a 39.5 percent increase in work-related fatalities from 15.7 per 100,000 full-time workers in 1992 to 21.9 in 1994. Other occupations, however, have shown improvement. The death rate among farm workers declined 27 percent. From 1992 to 1994, the death rate from construction-related accidents remained below the Year 2000 goal.

\section{Figure 8}

Objective 7.1:

Homicide rates, age-adjusted per 100,000 population:

North Carolina, 1990-1995

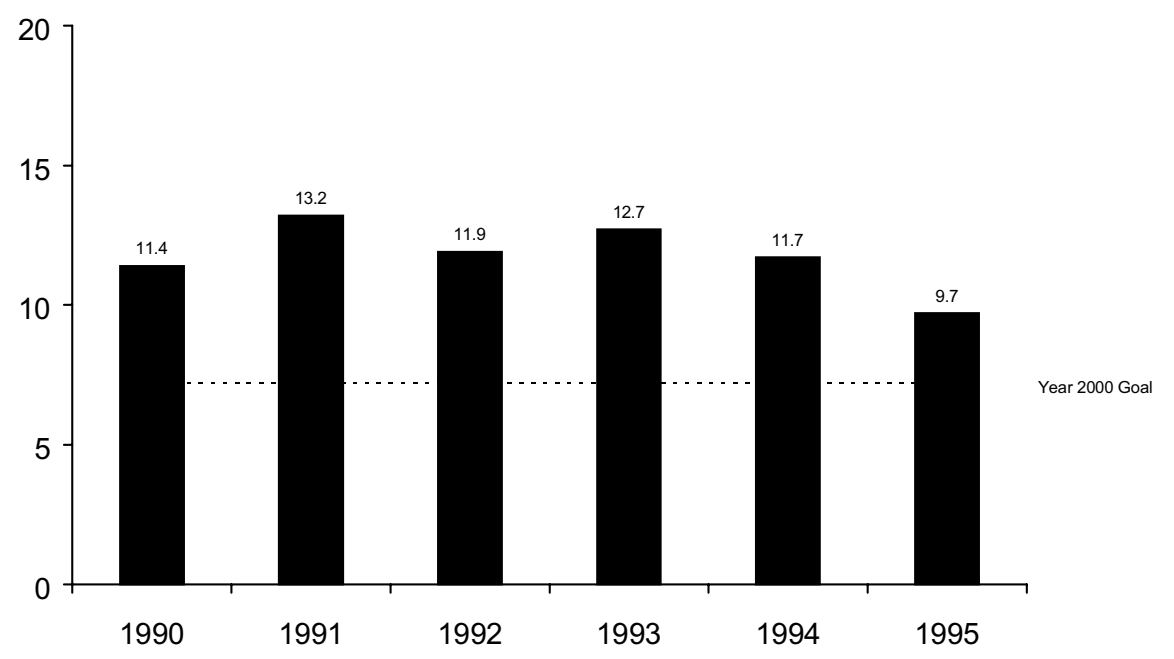

Source: State Center for Health Statistics 


\section{Figure 9}

Objectives 9.1, 9.3:

Injury death rates, age-adjusted per 100,000 population:

North Carolina, 1990-1995

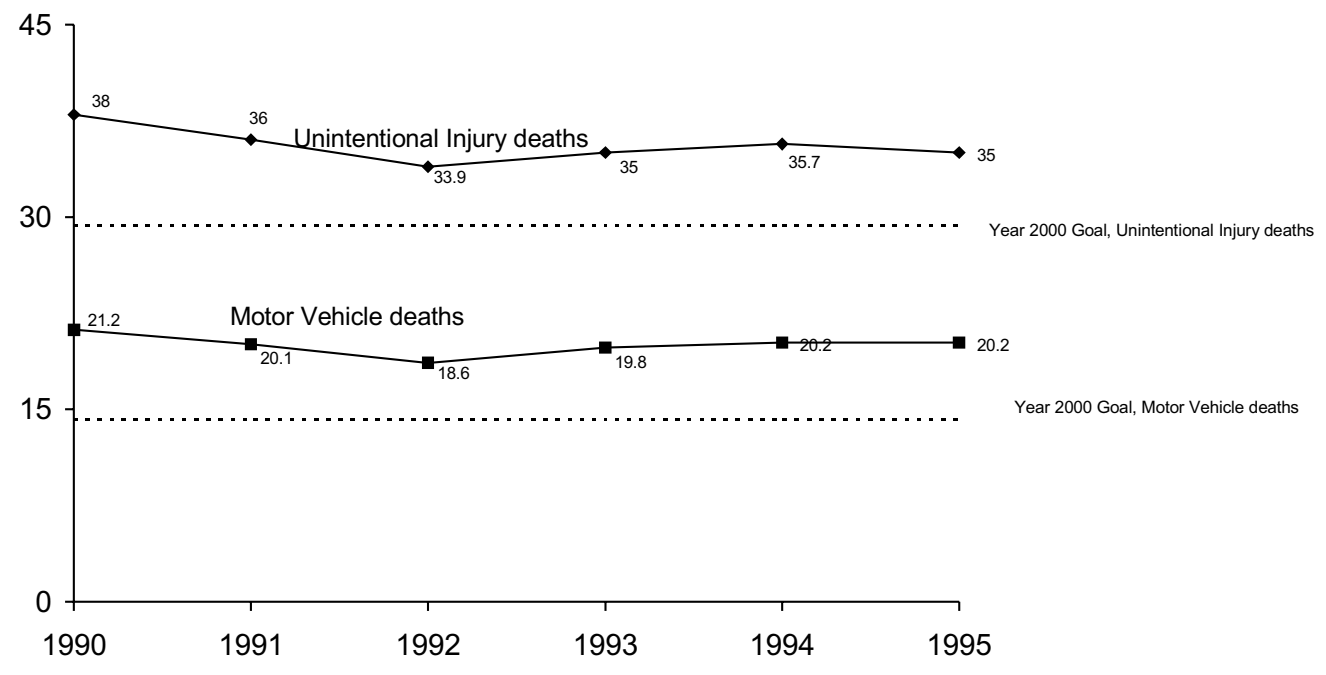

Source: State Center for Health Statistics

Figure 10

Objectives 9.2, 9.7, 9.9:

Hospitalization rates, per 100,000 population:

North Carolina, 1990-1993

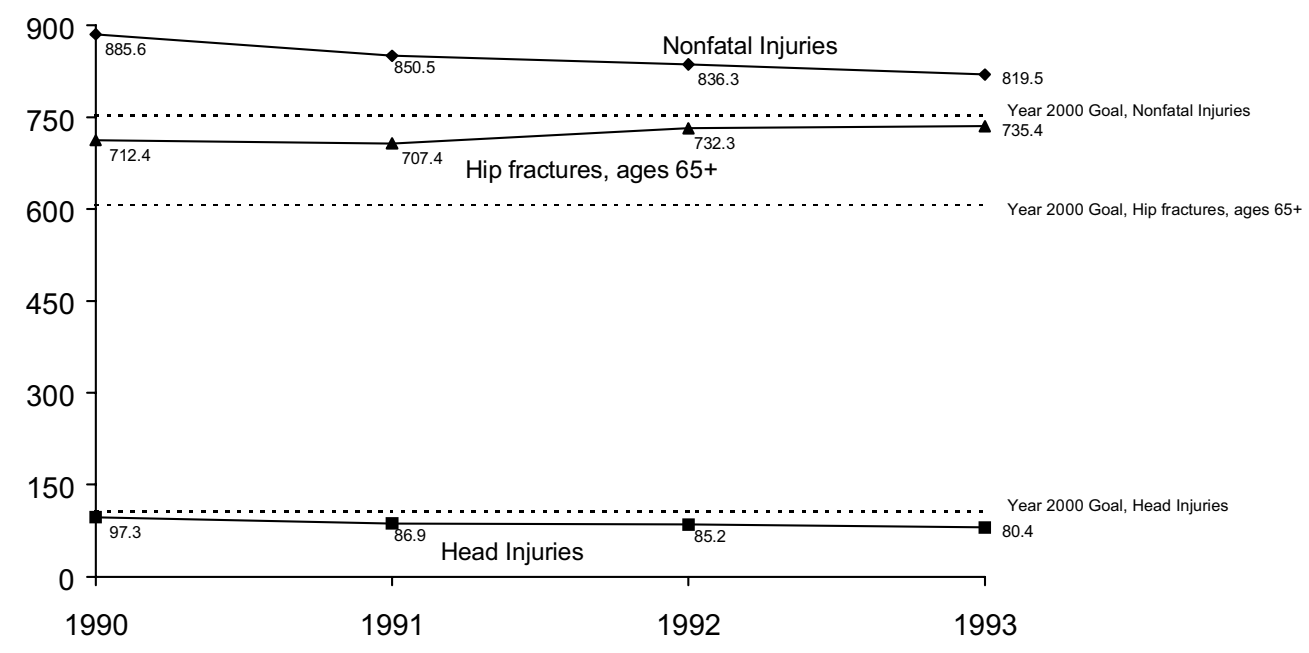

Source: State Center for Health Statistics 


\section{Figure 11}

Objective 10.1:

Work-related death rates, per 100,000 full-time employees:

North Carolina, 1992-1994

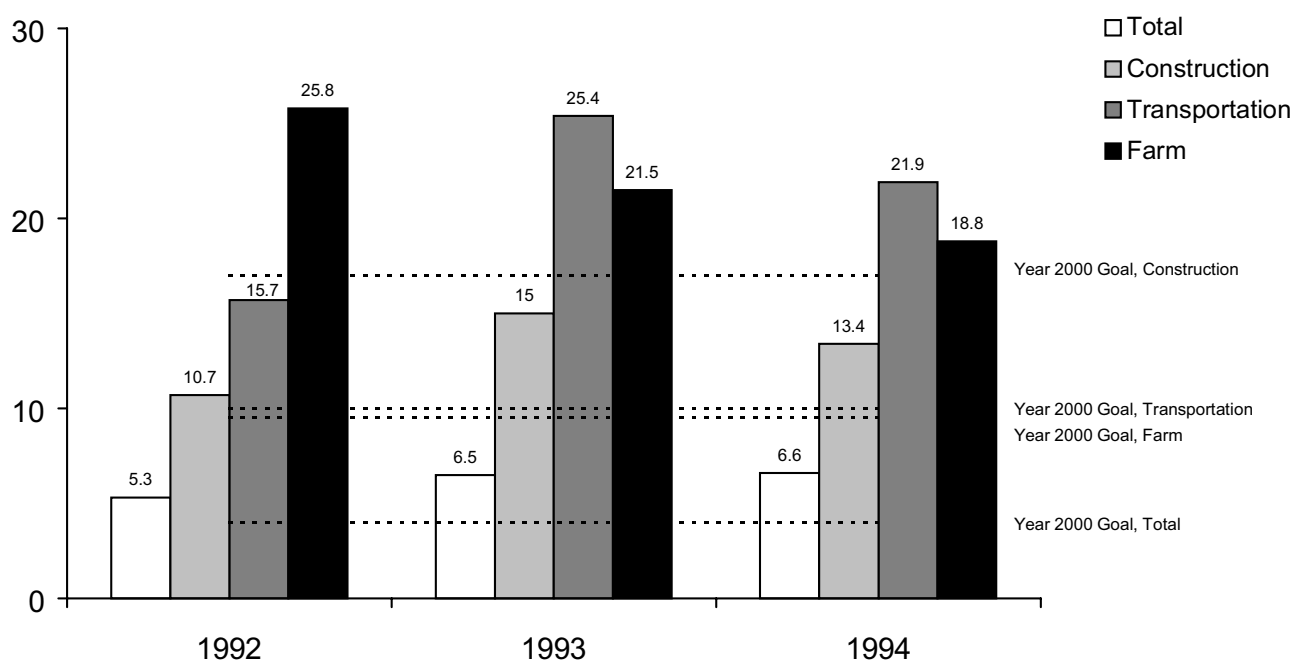

Source: North Carolina Department of Labor

Figure 12

Objective 10.2:

Work-related injury rates, per 100 full-time employees:

North Carolina, 1990-1994

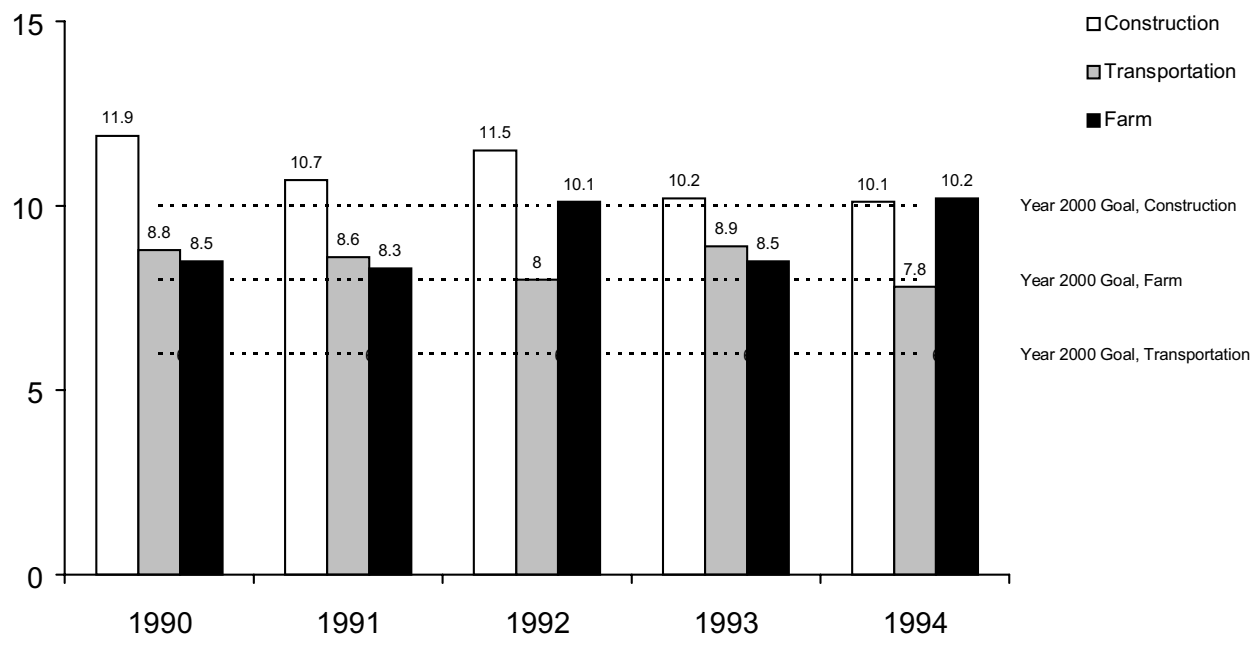

Source: North Carolina Department of Labor 
Figure 12 shows the state's work-related injury rates. In contrast to the fatality rate for transportation workers, which increased between 1992 and 1994, injuries among transportation workers decreased from 8.8 to 7.8 per 100 full-time workers between 1990 and 1994. The injury rate among construction workers also decreased between 1990 and 1994. Farm workers experienced a 20 percent increase in the work-related injury rate and moved away from the Year 2000 target of 8.0 per 100 full-time workers.

\section{Environmental Health}

Environmental exposures can contribute to many diseases and public health hazards. Asthma hospitalizations is one area for which there exists good data. Although nationally the prevalence of asthma mortality and morbidity has increased in recent years, North Carolina has consistently had an asthma hospitalization rate below the Year 2000 goal since 1990 (Figure 13).

\section{Maternal and Infant Health}

Infant mortality and the factors associated with infant health are a national priority and a particular concern to North Carolina because the state consistently ranks among the worst states in infant mortality. However, the state is making significant progress in reducing infant mortality. A record low rate of 9.2 infant deaths per 1,000 live births was achieved in 1995 (Figure 14). Although the black infant mortality rate also is declining, there is still a great disparity in infant deaths among different racial groups.

Low birthweight contributes to poor infant health. The percentage of babies born weighing less than 2,500 grams in North Carolina increased from 1990 to 1993 but remained stable between 1993 and 1995 (Figure 15). In contrast, the prevalence of low birthweight among blacks has risen consistently since 1990. The national trends also show that low birthweight percentages are increasing, partly due to an increase in preterm births (Midcourse Review, 1995).

\section{Figure 13}

Objective 11.1:

Asthma hospitalization rates, per 100,000 population:

North Carolina, 1990-1993

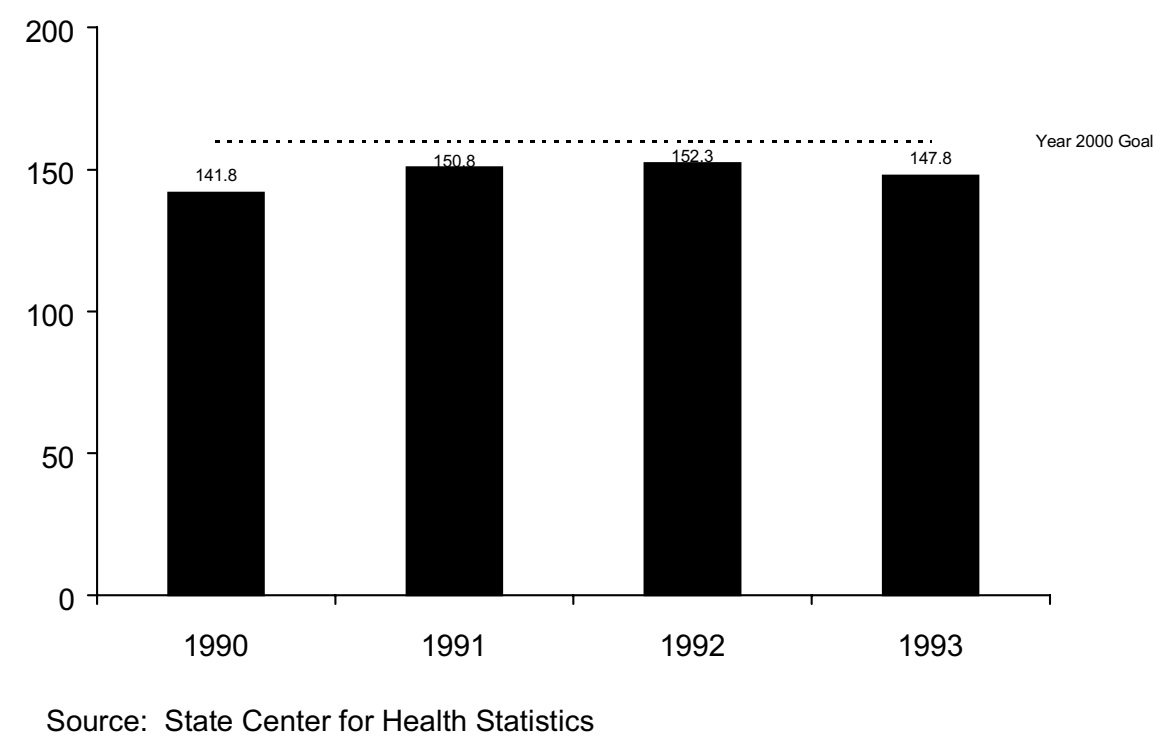




\section{Figure 14}

Objective 14.1:

Infant mortality rates, per 1,000 live births:

North Carolina, 1990-1995

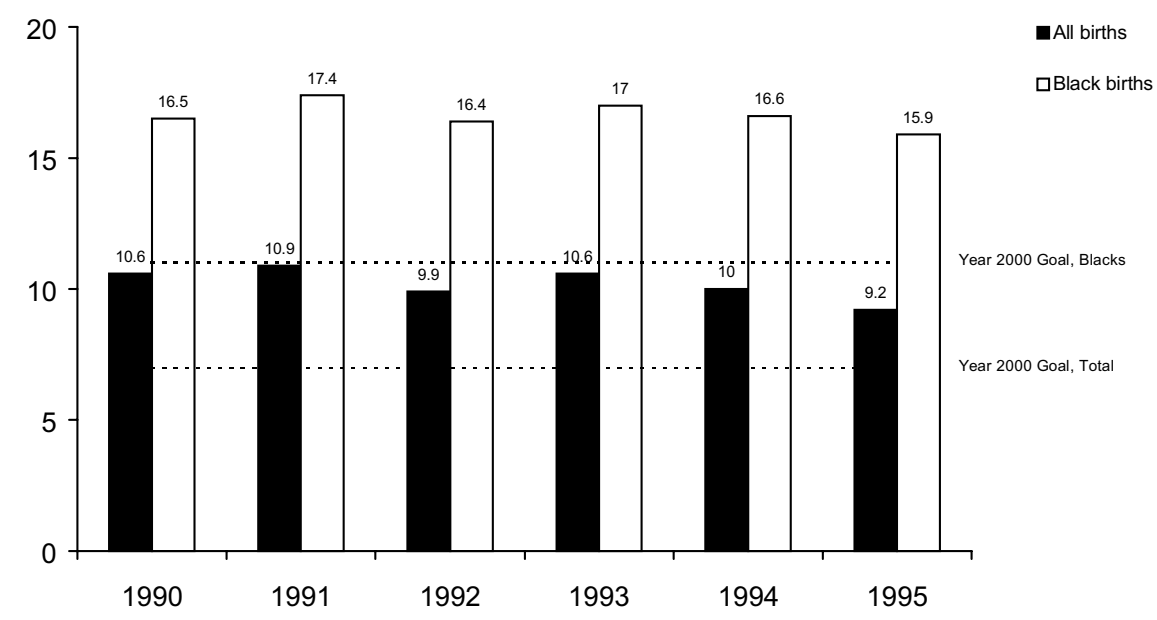

Source: State Center for Health Statistics

\section{Figure 15}

Objective 14.5:

Percentage of Low Birthweight Births (less than 2500 grams)

North Carolina, 1990-1995

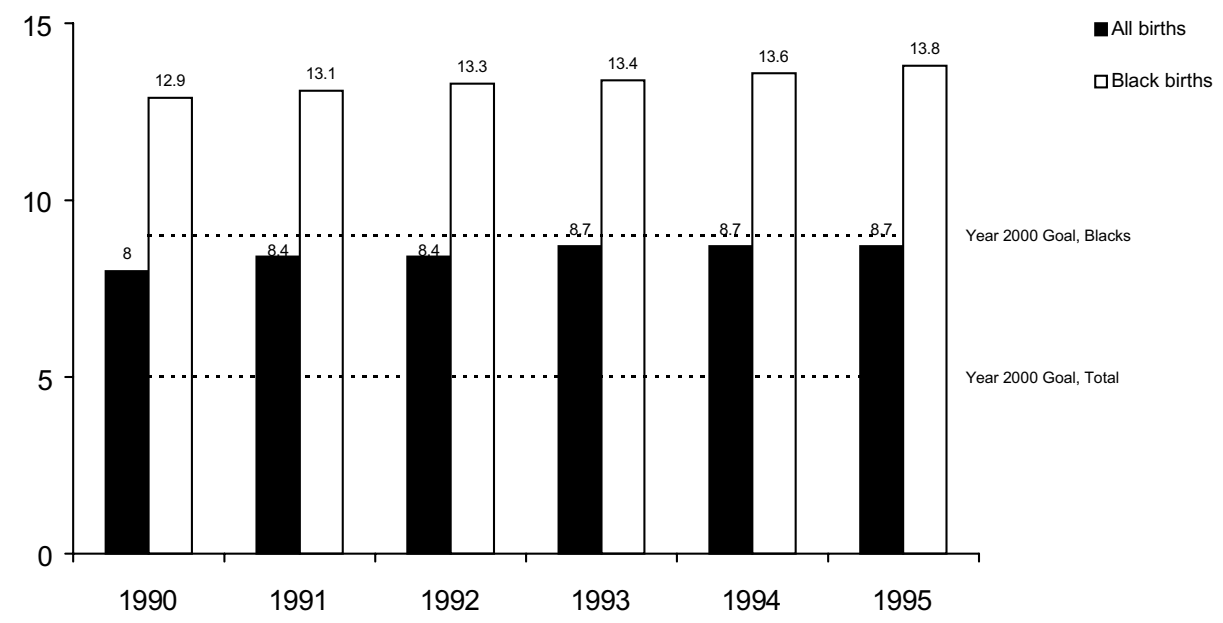

Source: State Center for Health Statistics 
Early prenatal care is associated with positive birth outcomes. North Carolina data shows an increasing pattern of receiving prenatal care in the first trimester for all women (Figure 16). The Year 2000 goal is 90 percent; and the 1995 rate for all women was 83 percent. The same year, 70.9 percent of black women received early prenatal care.

\section{Heart Disease and Stroke}

Heart disease and stroke are among the leading causes of death in North Carolina, as well as in the nation. Age-adjusted death rates for both of these diseases have been declining in the state since 1990, 14 percent for coronary heart disease deaths but only three percent for stroke deaths (Figure 17).

Behavioral modifications, such as better diet and exercise, can contribute to reducing heart disease and stroke morbidity and death. Benefits of proper diet and exercise include lower blood pressure and a reduction in the harmful effects of high blood pressure. Although the state has achieved the Year 2000 goal recommending that at least 90 percent of adults have their blood pressure checked at least every two years, Table 3 indicates that fewer North Carolinians ages 18 and older reported having their blood pressure checked in 1995 than in 1991. Public awareness and education on prevention and lifestyle changes should be emphasized in this priority area.

\section{Cancer}

Cancer is another leading cause of morbidity and death in the nation and in North Carolina. Relative to the United States and the national Year 2000 goals, the state is doing well in reducing cancer death rates and increasing screening practices.

Total cancer deaths declined slightly from 135.1 to 133.2 per 100,000 population during the six-year period between 1990 and 1995 (Figure 18). The breast cancer death rate also showed a decreasing trend and is now on par with the Year 2000 goal of 20.6. North Carolina has achieved the national goals for lung and colorectal cancer death rates, with rates of 40.6 and 13.0 per 100,000 population, respectively.

\section{Figure 16}

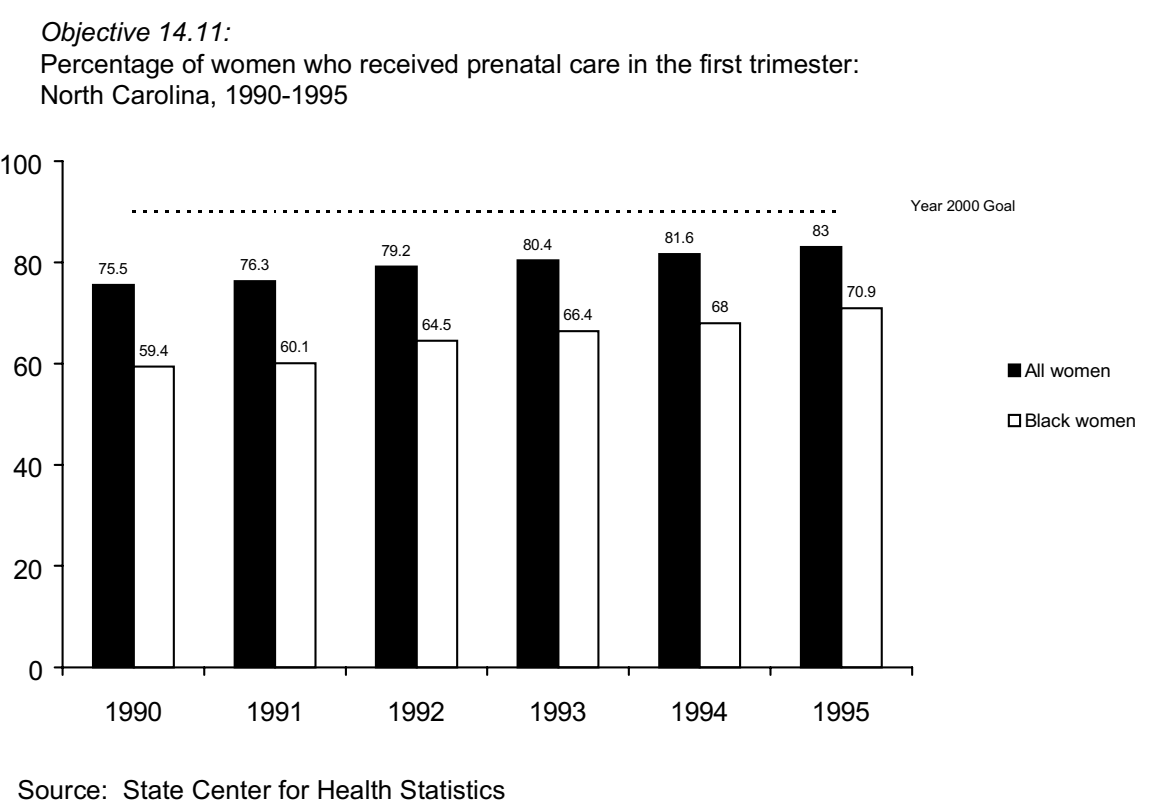




\section{Figure 17}

Objectives 15.1, 15.2:

Coronary Heart Disease and Stroke death rates, age-adjusted per 100,000 population: North Carolina, 1990-1995

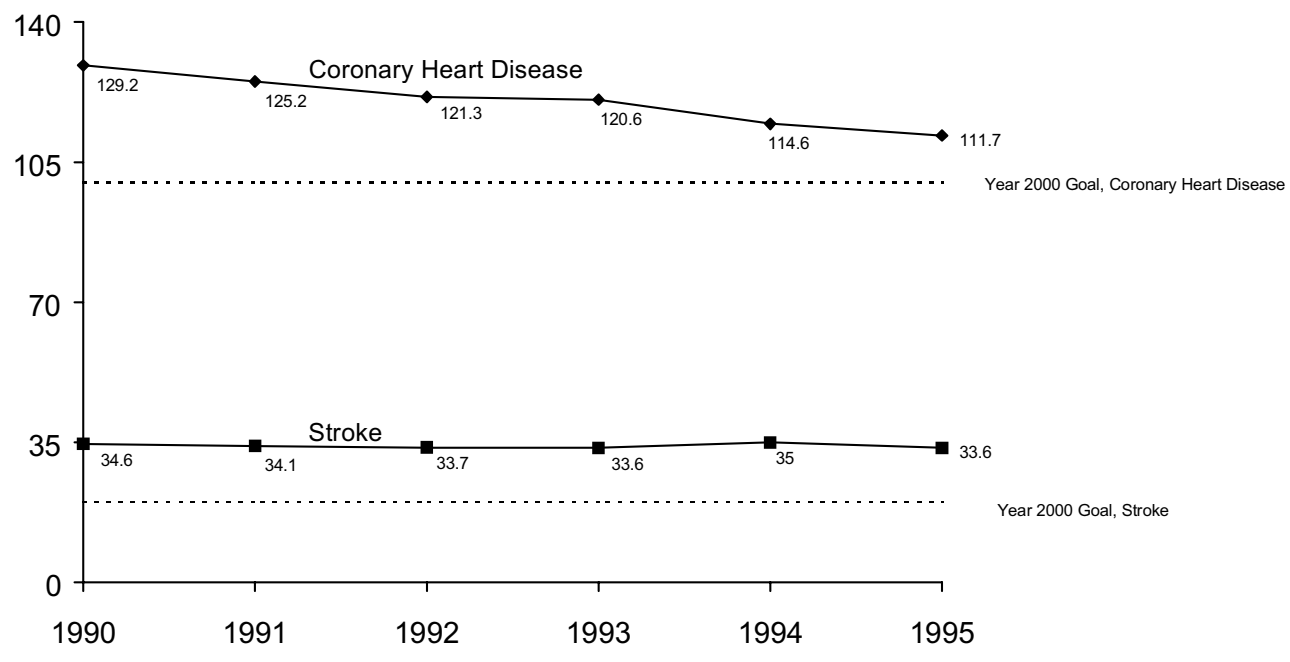

Source: State Center for Health Statistics

Table 3

\begin{tabular}{|l|cccc|c|}
\hline \multirow{2}{*}{ Objective } & \multicolumn{3}{|c|}{ North Carolina Percentages } & Year \\
\cline { 2 - 5 } & $\mathbf{1 9 9 1}$ & $\mathbf{1 9 9 2}$ & $\mathbf{1 9 9 3}$ & $\mathbf{1 9 9 5}$ & $\mathbf{2 0 0 0}$ Goal \\
\hline $\begin{array}{c}\text { 15.13 Blood pressure checked within the } \\
\text { preceding two years, ages 18+ }\end{array}$ & 96.0 & 96.1 & 94.9 & 92.8 & 90.0 \\
\hline \multicolumn{2}{|l|}{} \\
\hline \multicolumn{2}{|l|}{ Source: Behavioral Risk Factor Surveillance System, Division of Health Promotion } \\
\hline
\end{tabular}




\section{Figure 18}

Objectives 16.1, 16.2, 16.3, 16.5:

Cancer death rates, age-adjusted per 100,000 population:

North Carolina, 1990-1995

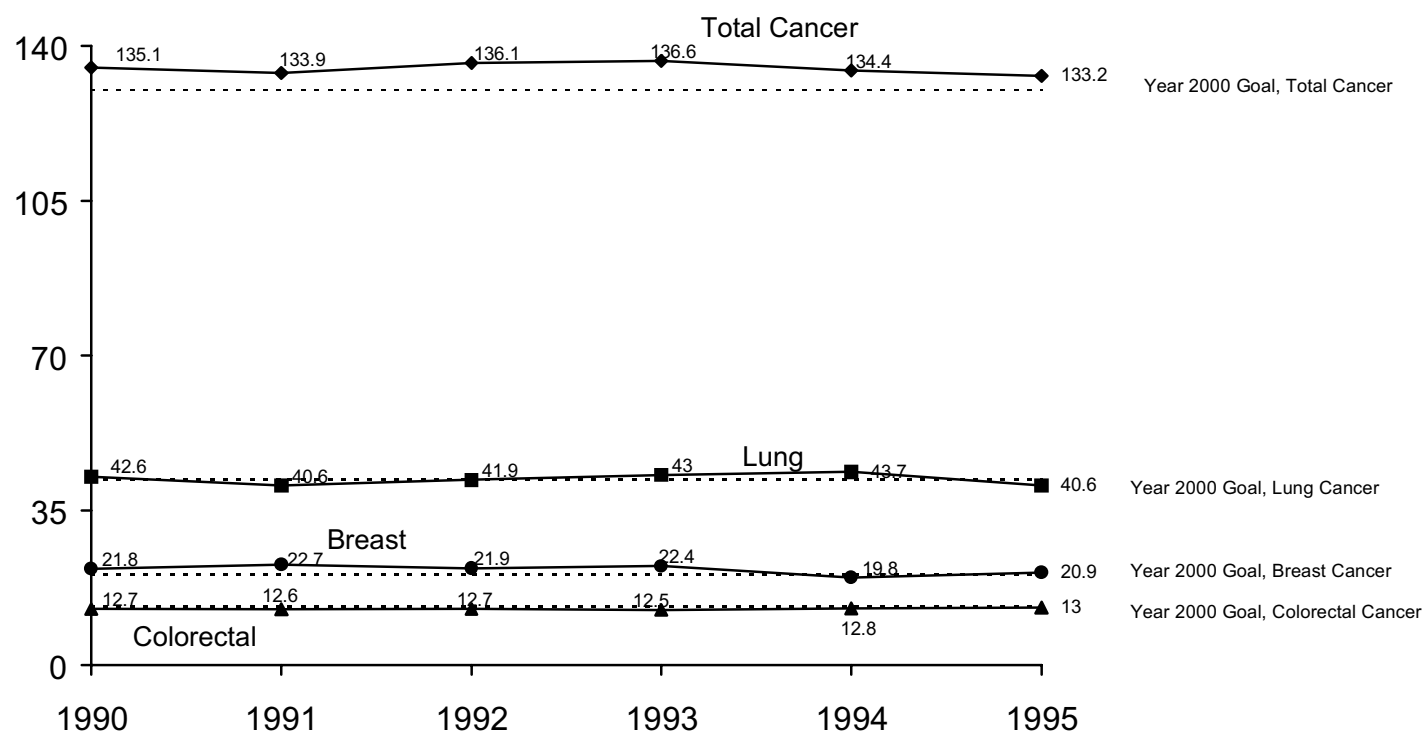

Source: State Center for Health Statistics

\section{Table 4}

\begin{tabular}{|c|c|c|c|c|c|c|c|c|}
\hline & & \multicolumn{6}{|c|}{ North Carolina Percentages } & \multirow{2}{*}{$\begin{array}{c}\text { Year } \\
2000 \text { Goal }\end{array}$} \\
\hline \multicolumn{2}{|c|}{ Objective } & 1990 & 1991 & 1992 & 1993 & 1994 & 1995 & \\
\hline 16.11 & $\begin{array}{l}\text { Breast exam and mammogram } \\
\text { within preceding two years, } \\
\text { females ages } 50+\end{array}$ & 55.9 & 59.7 & 59.0 & 63.6 & 63.5 & 63.3 & 60.0 \\
\hline $16.11 \mathrm{e}$ & $\begin{array}{l}\text { Breast exam and mammogram } \\
\text { within preceding two years, } \\
\text { black females ages } 50+\end{array}$ & 46.2 & 50.4 & 52.5 & 59.0 & 49.3 & 62.1 & 60.0 \\
\hline 16.12 & $\begin{array}{l}\text { Pap smear within preceding } \\
\text { two years, females ages } 18+ \\
\text { (with no history of hysterectomy) }\end{array}$ & 80.7 & 90.3 & 83.9 & 84.9 & 87.0 & 85.9 & 85.0 \\
\hline
\end{tabular}


The cancer priority area emphasizes screening and early detection as effective ways to reduce cancer incidence and mortality. For women, screening tests include clinical breast exams, mammograms, and pap smears. In North Carolina, the proportion of women using these tests has increased over time. Females of all races ages 50 and older and black females ages 50 and older achieved the Year 2000 goal of at least 60.0 percent having received a clinical breast exam and mammogram in the preceding two years (Table 4). In addition, the proportion of women ages 18 and older with no history of hysterectomy who received a pap smear within the preceding two years increased from 80.7 to 85.9 percent between 1990 and 1995 .

\section{Diabetes and Chronic Disabling Conditions}

Although there is limited data available at the state level on chronic disabling conditions, North Carolina does have access to information on diabetes deaths and prevalence. Figure 19 reveals that diabetes-related death rates have remained relatively stable since 1990, but significant progress is needed to attain the Year 2000 goal of 34.0 per 100,000 population.

Diabetes prevalence is difficult to estimate because so many people unknowingly have the disease. However, Figure 20 shows weighted diabetes prevalence rates among North Carolina adults from the Behavioral Risk Factor Surveillance System. The system is based on survey participants' reports of whether a health care professional has ever told them that they had diabetes, excluding diabetes diagnosed only in pregnancy. Prevalence rates both for the total adult population and for the black adult population show progress toward reaching the Year 2000 goals. For all races, the diabetes prevalence rate decreased 24 percent from 1990 to 1995; and there was a 17 percent decline among the black population.

\section{Figure 19}

Objective 17.9:

Diabetes-related death rates, age-adjusted per 100,000 population:

North Carolina, 1990-1995

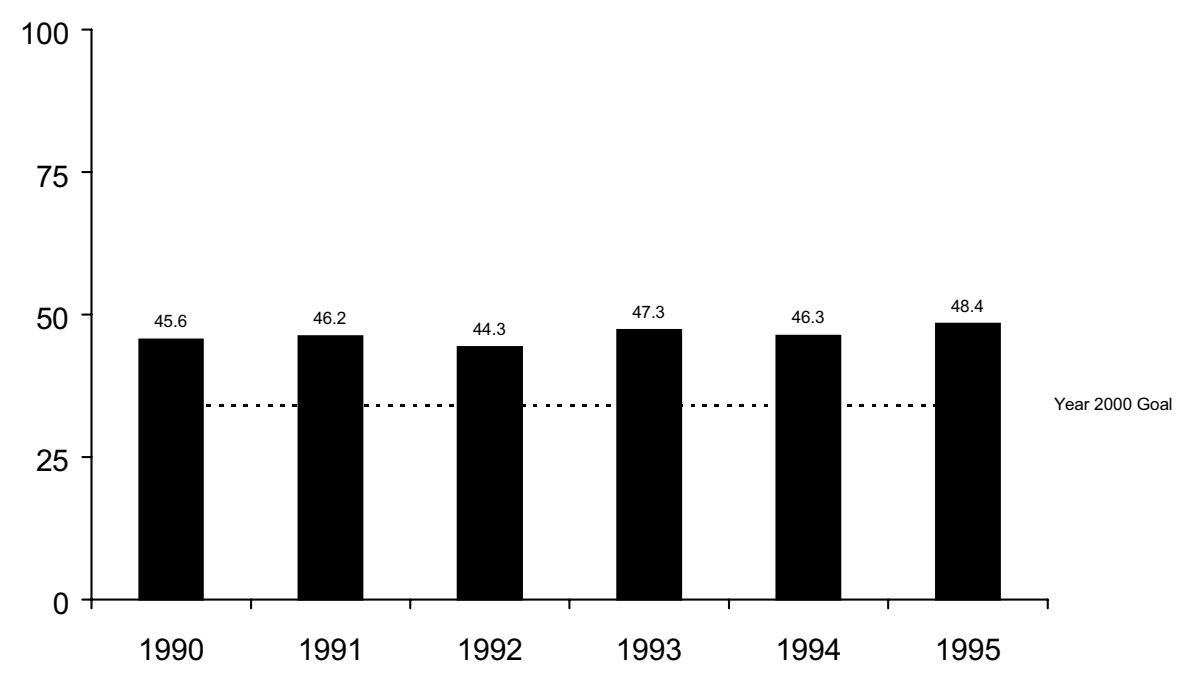

Source: State Center for Health Statistics 


\section{Figure 20}

Objective 17.11:

Diabetes prevalence rates, per 1,000 population:

North Carolina, 1990-1994

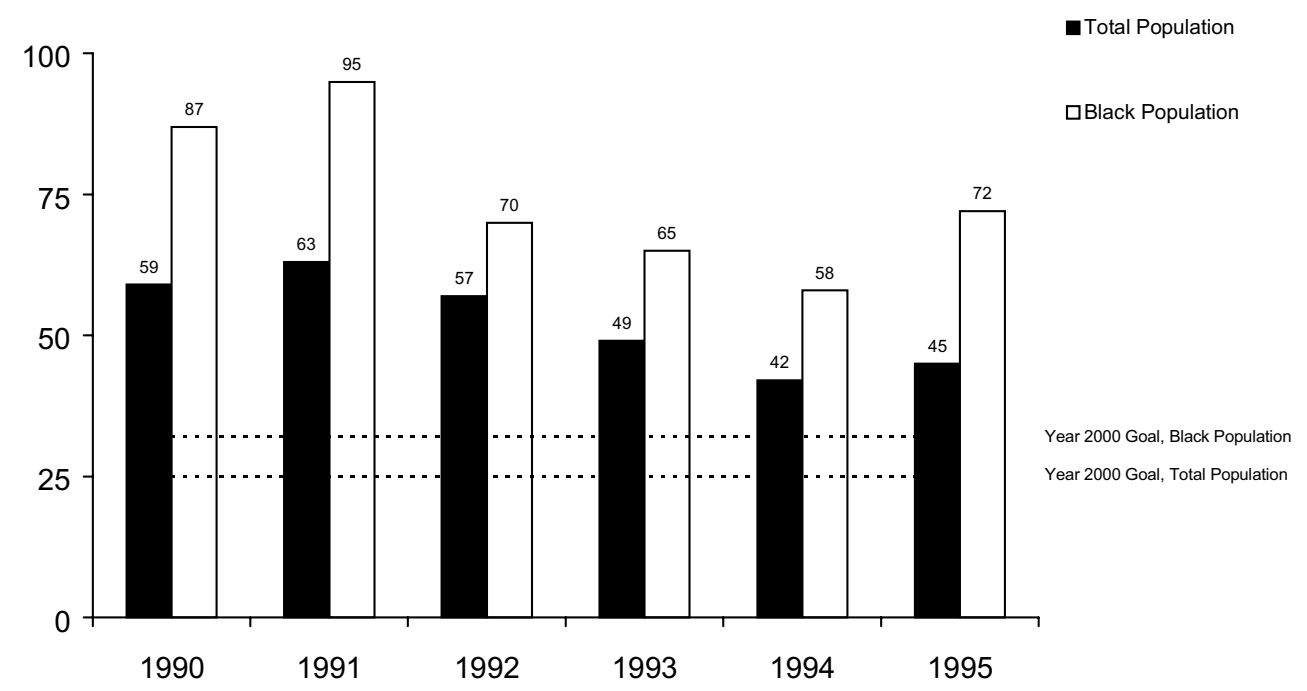

Source: Behavioral Risk Factor Surveillance System, Division of Health Promotion

\section{Figure 21}

Objective 18.1:

AIDS prevalence rates, per 100,000 population:

North Carolina, 1990-1995

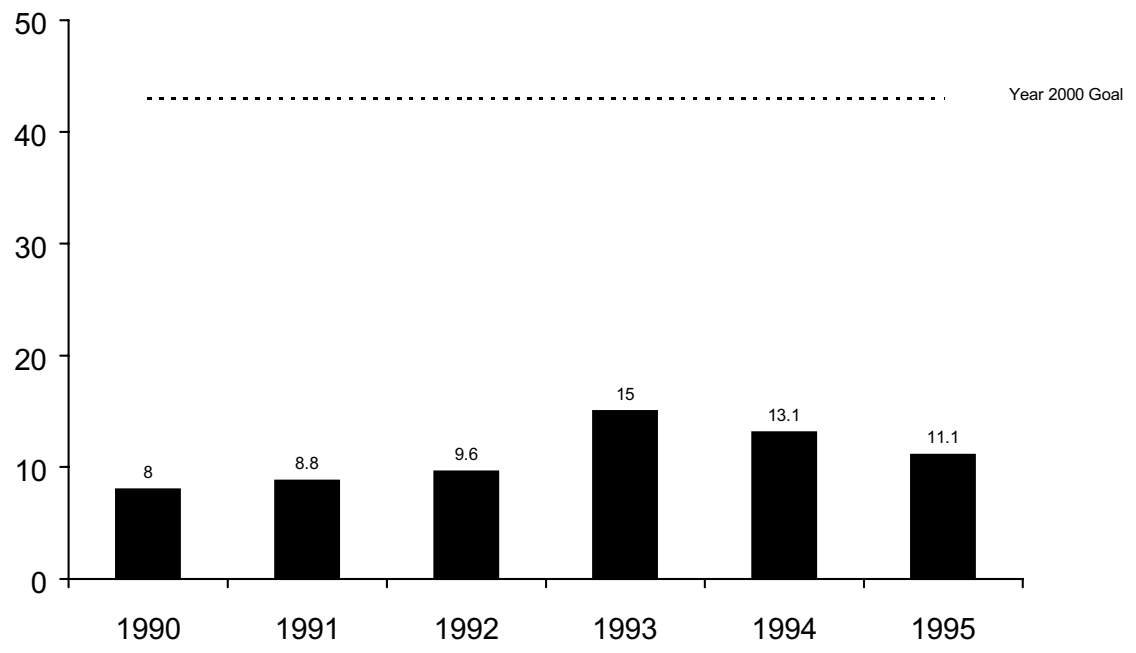

Source: HIVISTD Control Branch

Division of Epidemiology 


\section{Figure 22}

Objective 19.1:

Gonorrhea prevalence rates, per 100,000 population:

North Carolina, 1990-1995

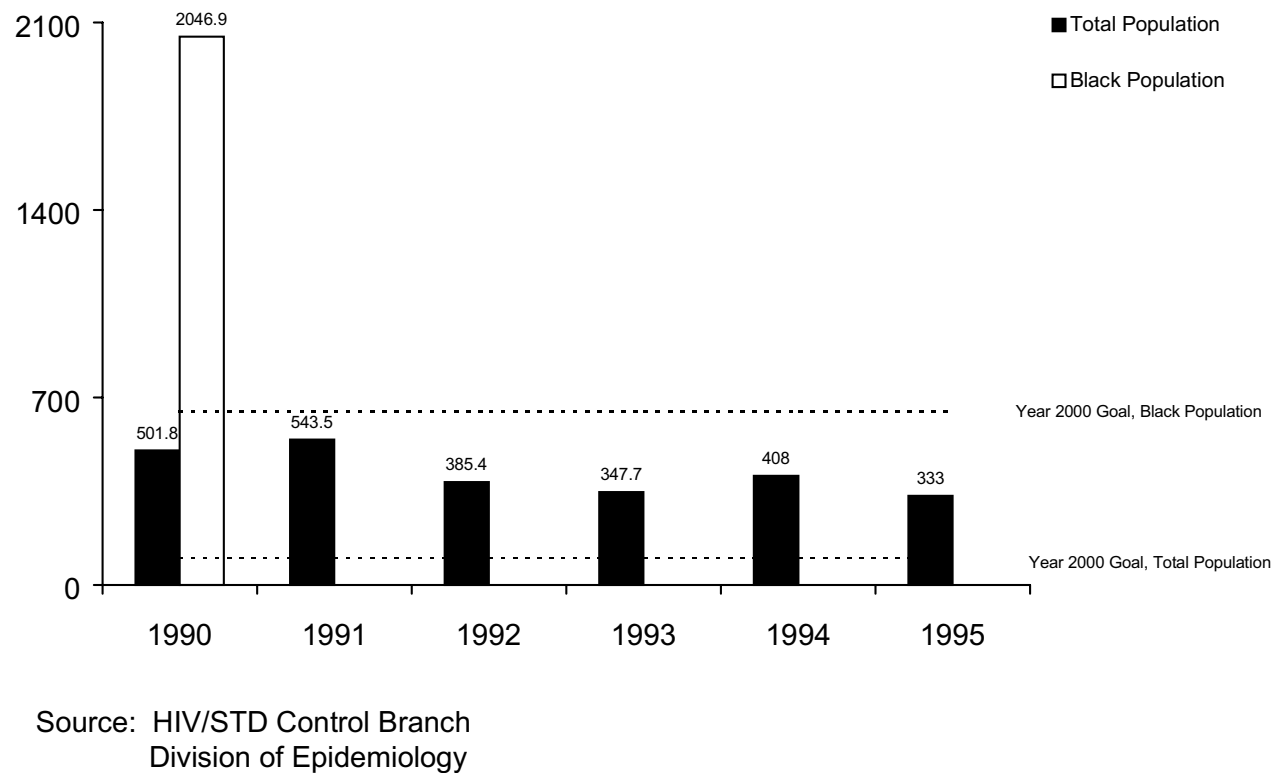

\section{HIV Infection}

In 1995, North Carolina had an AIDS prevalence rate of 11.1 per 100,000 population, already significantly below the national goal of 43.0 (Figure 21). However, the rate shows an increasing trend and has risen 39 percent since 1990. AIDS and HIV education should continue to focus on prevention and modification of high-risk behaviors.

\section{Sexually Transmitted Diseases}

Sexually transmitted diseases (STDs) among youth are highlighted in the Year 2000 Child Health Objectives study (Waller, 1997). Gonorrhea incidence decreased for the total population by 34 percent from 501.8 per 100,000 population in 1990 to 333.0 in 1995 (Figure 22). In addition, primary and secondary syphilis rates decreased 41 percent during that six-year period from 26.4 per 100,000 population to 15.7 (Figure 23). These declines parallel the national trend of declining STD rates.

\section{Immunization and Infectious Diseases}

The objectives in this priority area seek to decrease vaccine-preventable and other infectious diseases and to increase the proportion of children and adults who are appropriately immunized. Figure 24 highlights the 28 percent decline in tuberculosis case rates in North Carolina since 1990. Unlike the nation as a whole, North Carolina is moving toward the Year 2000 goal for case rates of tuberculosis.

Another area where North Carolina shows great progress is childhood immunizations. Despite some problems with data consistency, Table 5 shows that the percent of children entering kindergarten who are immunized appropriately has been at or above the Year 2000 goal since 1990.

Table 6 shows some immunization data for older populations. People ages 65 and older are progressing toward the Year 2000 goals both in terms of the proportion who have received an influenza vaccination in 


\section{Figure 23}

Objective 19.3:

Primary/Secondary Syphilis prevalence rates, per 100,000 population:

North Carolina, 1990-1995

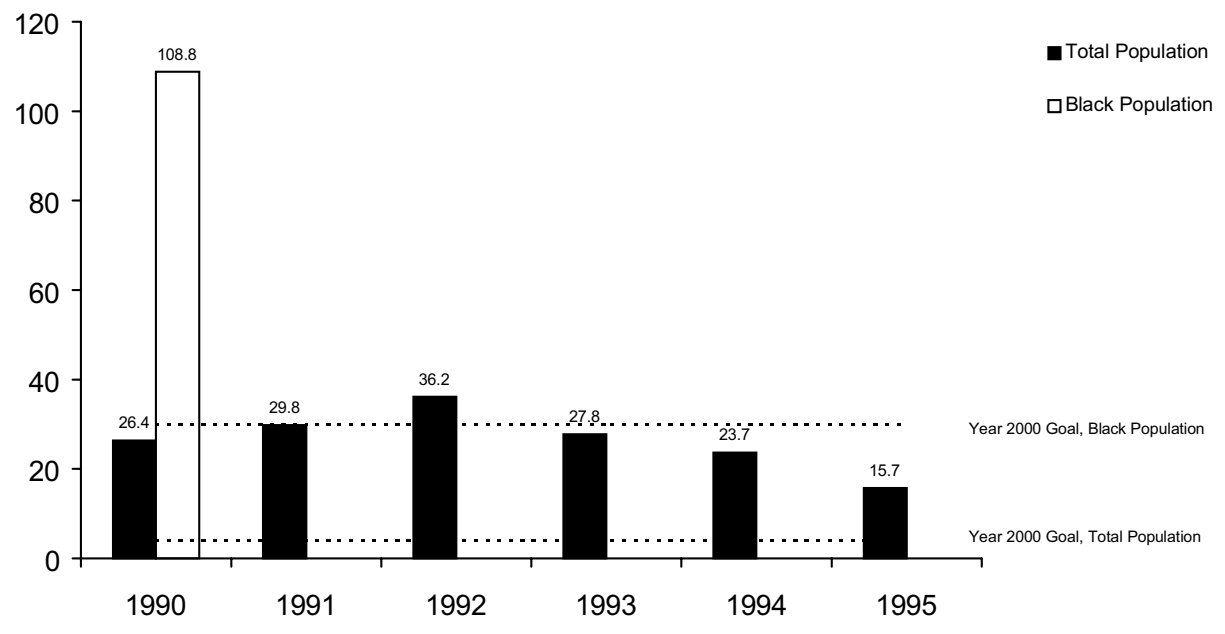

Source: HIVISTD Control Branch Division of Epidemiology

\section{Figure 24}

Objective 20.4:

Tuberculosis prevalence rates, per 100,000 population:

North Carolina, 1990-1995

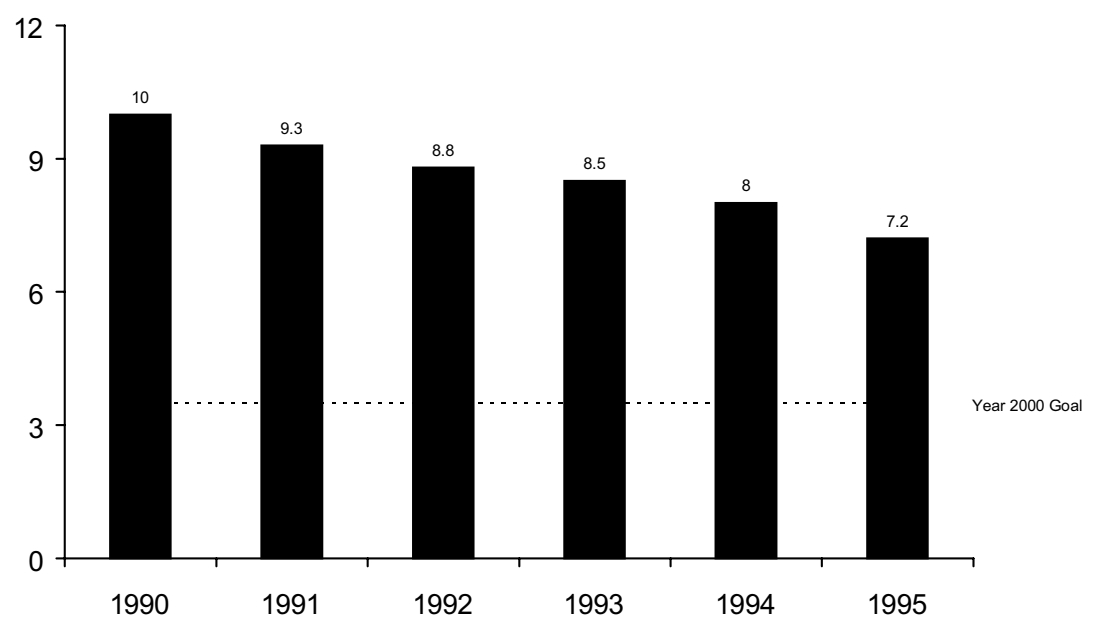

Source: State Center for Health Statistics

Communicable Disease Surveillance Data System 


\section{Table 5}

\begin{tabular}{|c|c|c|c|c|c|c|}
\hline \multirow[b]{2}{*}{ Objective } & \multicolumn{5}{|c|}{ North Carolina } & \multirow{2}{*}{$\begin{array}{c}\text { Year } \\
2000 \text { Goal }\end{array}$} \\
\hline & 1990 & 1991 & 1992 & 1994 & 1995 & \\
\hline \multicolumn{7}{|l|}{$\begin{array}{c}\text { 20.11 Percentage immunized } \\
\text { appropriately among: }\end{array}$} \\
\hline Children in day care & 93.0 & 83.9 & 88.0 & 90.5 & - & 95.0 \\
\hline Children entering kindergarden & 95.0 & 96.8 & 97.8 & 98.0 & 98.3 & 95.0 \\
\hline
\end{tabular}

\section{Table 6}

\begin{tabular}{|c|c|c|c|c|}
\hline \multirow[b]{2}{*}{ Objective } & \multicolumn{3}{|c|}{ North Carolina Percentages } & \multirow{2}{*}{$\begin{array}{c}\text { Year } \\
2000 \text { Goal }\end{array}$} \\
\hline & 1993 & 1994 & 1995 & \\
\hline $\begin{array}{l}21.2 \text { Influenza vaccine received in last year, } \\
\text { ages } 65+\end{array}$ & 50.9 & - & 52.2 & 60.0 \\
\hline $\begin{array}{l}21.2 \text { Pneumococcal vaccine ever received, } \\
\text { ages } 65+\end{array}$ & 26.3 & - & 30.7 & 60.0 \\
\hline 21.2 Routine check-up in last two years & 84.3 & 81.9 & 82.6 & 91.0 \\
\hline 21.3 Access to primary care & - & 80.5 & - & 95.0 \\
\hline $21.3 \mathrm{~b}$ Access to primary care, Blacks & - & 78.0 & - & 95.0 \\
\hline 21.4 People with no health insurance, ages $<65$ & - & 10.8 & - & 0.0 \\
\hline $21.4 \mathrm{c}$ People with no health insurance, Blacks $<65$ & - & 13.8 & - & 0.0 \\
\hline
\end{tabular}


the last year and in the proportion who have ever received a pneumococcal vaccination.

\section{Clinical Preventive Services}

Prevention, education, and health behavior modification can improve the quality of life. The Clinical Preventive Services objectives target areas of prevention, such as immunizations, delivery of services, and access to care, in order to encourage the nation to practice healthful living.

One way to monitor health is through routine check-ups. In 1995, 82.6 percent of North Carolina adults reported receiving a routine check-up within the past two years (Table 6), a figure below the national goal of 91 percent.

The North Carolina Health Profile Survey, administered in 1994, provides information on the state population's access to health care and to health care coverage. Data is only available for one year. The state has not achieved the Year 2000 target of 95 percent either for all races or for blacks in terms of the proportion of adults who reported having a specific source of ongoing, primary care (Table 6). In $1994,80.5$ percent of the total population and 78.0 percent of the black population had regular access to primary care.

Another national concern is health insurance coverage. By the year 2000, the nation seeks to reduce to zero the proportion of people under age 65 who have no health insurance. Currently, 10.8 percent of all and 13.8 percent of black North Carolinians lack health insurance coverage (Table 6).

\section{DISCUSSION}

This review of North Carolina's progress on a small sample of the national Healthy People 2000 goals reveals several important findings. First, North Carolina has shown significant improvement in some areas. Second, efforts directed to improve the health status and health behavior of the state's youth need to be emphasized. Finally, all citizens need to be educated about the benefits of adopting a healthy lifestyle.

Since 1990, North Carolina has moved in the right direction toward achieving many of the national Year 2000 objectives; and by 1995, the state had already surpassed some of the goals. For example, cigarette smoking prevalence is declining, and participation in vigorous physical activity has increased since 1990. In addition, death rates for unintentional injury, homicide, and suicide have decreased during the sixyear period between 1990 and 1995.

Health and safety in the state's workplaces are improving as evidenced by the reduction in work-related injuries and fatalities across many industries. Infant health, a particular concern for North Carolina, shows progress by the declining rate of infant mortality and the effort by more women to seek prenatal care in the first trimester of pregnancy. Death rates for lung cancer and colorectal cancer have currently surpassed the Year 2000 goals, and reductions in other chronic disease death rates are occurring as well. Finally, North Carolina shows high percentages of both young children and older adults who are appropriately immunized, which emphasizes the state's commitment to prevention and wellness.

The data available on North Carolina's youth indicates that they have poor eating and exercise habits and engage in other high risk behaviors. Although cigarette use among adolescents has declined somewhat, both alcohol and marijuana use have increased. State level data is limited related to black adolescent pregnancy rates, but national trends indicate that these rates are increasing. Rates of suicide deaths also are increasing for ages 15-19.

A more extensive analysis of child and adolescent performance on the Year 2000 goals is available in a previous study (Waller, 1997). As in the earlier report, the data here shows that special attention needs to be focused on the youth in North Carolina. Attitudes toward health are learned at an early age, and the state should play a role in increasing safe, healthy behaviors among children. 
The information included in this report shows that North Carolina is moving in the wrong direction for 19 of the Year 2000 objectives, especially in the priority areas of physical activity, nutrition, substance abuse, and infant health. Progress is dependent upon behavioral change, which can be influenced by increased education.

Lifestyle changes are occurring: for example, more North Carolinians are engaging in vigorous physical activity and having their blood cholesterol levels checked. However, overweight prevalence and sedentary lifestyles are increasing. Good nutrition and regular exercise have many proven health benefits such as reducing the risk of disease and increasing the span of healthy life, one of the fundamental goals of the Healthy People 2000 program. Physical activity is especially important for the state's aging population in order to encourage healthy, independent living.

Another area where North Carolina falls short of the national goal is the number of low birthweight births for all populations. Educating mothers during the prenatal period about proper nutrition and safe behavior is just one of the methods that can be used to promote the healthy development of babies.

The rate of diabetes-related deaths in North Carolina is moving away from the Year 2000 goal. There is a great deal of information on treating and preventing diabetes-related conditions such as blindness and renal disease. The appropriate populations may not be targeted early, however, because incidence is unknown or under-reported. The state needs to work towards detecting diabetes in its early stages so that chronic conditions and unnecessary deaths can be prevented.

Although there was a slight decrease between 1993 and 1995 in the proportion of people who received a routine check-up, North Carolinians continue to be aware of the benefits of screening to promote disease prevention. The state has surpassed the Year 2000 goals for the proportion of adults who have had their blood pressure measured and of women who have received clinical breast exams and mammograms.
For the sample of Year 2000 objectives presented in this study, North Carolina shows a wide range in its level of progress, from moving in the wrong direction to already achieving the established goal. The state has made many advances in reducing disease and promoting health and wellness among its citizens. Statewide efforts in prevention and education must continue in order to see progress in other areas.

The goals of Healthy People 2000 are to increase the span of healthy life, to reduce health disparities, and to achieve access to preventive services. These are goals not just to be achieved but to be maintained. Healthful living provides a vision and an on-going challenge for the state and the nation, for the Year 2000 and beyond.

\section{DATA GAPS AND LIMITATIONS}

This report focuses on North Carolina's progress toward reaching the Healthy People 2000 goals. Over 600 unique objectives and sub-objectives exist in the Healthy People 2000 Program. For many objectives, however, the state does not have the data necessary to measure trends. Excluding those that deal with data not pertinent for the states to collect, there are an estimated one-third to one-half of the objectives for which there are no North Carolina data or for which existing North Carolina data is unreliable. These data needs fall particularly under the priority areas of Education and Community-Based Programs, Environmental Health, Food and Drug Safety, Oral Health, and Diabetes and Chronic Disabling Conditions.

Information may not be collected or may not be useful due to of one or more of the following reasons:

Data is collected at the local level, but there is no current mechanism to consolidate the information into statewide statistics.

- Collection of data is too costly.

Data items are self-reported, leading to unreliable results. 
- Funding for data collection is not consistently available over time.

- A significant segment of the population may be unaware that they have the disease, making it difficult to obtain accurate information. A good example is diabetes.

Data is available for some segments of the population, such as the elderly, but not for the entire population.

Among the data that is available, there are several general limitations that hinder the state's efforts to measure its progress toward achieving the Healthy People 2000 goals. First, in some cases data is available, but it has not been collected in the same way over time. For example, blood lead level measurements among children are based on different populations sampled over time. The same is true for immunization proportions.

Second, North Carolina may not collect the data exactly as stated in the national objective. Different age groups may be used or variables are not collected at all. The state's hospital discharge files have not included race, a breakdown often specified in the Year 2000 objectives. Additional areas where data is not compatible include child abuse, mental retardation, and alcohol-related motor vehicle deaths.

Third, under-reporting problems exist with some self-reported data. For example, the prevalence of obesity is underestimated by the BRFSS because people tend to under-report their weight.

A final limitation relevant to many objectives is the absence of data at the state level on small populations. The Healthy People 2000 objectives identify many small population groups because they are at high risk and need to be targeted. North Carolina data for groups such as Hispanics is limited because this ethnic group represents a small portion of the state's population. Statewide surveys such as the Behavioral Risk Factor Surveillance System are currently unable to report the results for small population subgroups (such as Hispanics) because of the limited sample sizes and correspondingly unstable subgroup rates.
The Healthy People 2000 Program provides a basis for North Carolina to assess the health status of its citizens and to target areas for improvement. Its strength lies in its emphasis on prevention and on achieving and maintaining healthy lifestyles. A weakness, however, lies in the fact that it has established some ambitious goals and that it has included some objectives for which current data is either unreliable or unavailable.

Throughout this process, the State Center has been interested in monitoring health status in its 100 counties as well as statewide. With national efforts beginning to update these objectives for the year 2010, emphasis should be placed on establishing realistic targets that are measurable at both the state and local level.

\section{REFERENCES}

Centers for Disease Control and Prevention. "Cigarette smoking-attributable mortality and years of potential life lost - United States, 1990." Morbidity and Mortality Weekly Report, Vol. 42, No. 33, pp. 645-49. Atlanta, Georgia: Public Health Service, 1993.

Centers for Disease Control and Prevention. "Youth Risk Behavior Surveillance - United States, 1995," Morbidity and Mortality Weekly Report, Vol. 45, No. SS-4. Atlanta, Georgia: Public Health Service, September 27, 1996.

Mikow, Victoria A., Alcohol, Tobacco, and Other Drug Use by 9th-12th Grade Students: Results from the 1993 North Carolina Youth Risk Behavior Survey. Division of Innovation and Development Services, Accountability Services Area, Department of Public Instruction, 1994.

Mikow, Victoria A., Selected Indicators of Adolescent Violence and Safety at School: Results from the 1993 North Carolina Youth Risk Behavior Survey. Division of Innovation and Development Services, Accountability Services Area, Department of Public Instruction, 1994. 
North Carolina Behavioral Risk Factor Surveillance System, Office of Epidemiology, Division of Health Promotion, Department of Environment, Health, and Natural Resources, 1990, 1991, 1992, 1993, 1994, 1995.

North Carolina Health Profile Survey. State Center for Health Statistics, Department of Environment, Health, and Natural Resources, 1994.

North Carolina Youth Risk Behavior Survey, North Carolina Department of Public Instruction, April, 1992.

U. S. Department of Health and Human Services Public Health Service. Healthy People 2000: Midcourse Review and 1995 Revisions. US Government Printing Office, Washington, October 1995.
U. S. Department of Health and Human Services Public Health Service. Healthy People 2000: National Health Promotion and Disease Prevention Objectives, DHHS Publication No. (PHS) 91-50212. US Government Printing Office, Washington, September 1990.

U. S. Department of Health and Human Services Public Health Service. Healthy People 2000: National Health Promotion and Disease Prevention Objectives, Healthy People 2000 Review 1995-96. DHHS Publication No. (PHS) 96-1256. Hyattsville, MD, 1996.

Waller, Cheryl. "North Carolina Performance on Year 2000 Child Health Objectives," SCHS Studies, No. 102. NC Department of Environment, Health, and Natural Resources, Raleigh, February, 1997. 
Appendix A

\begin{tabular}{|c|c|c|c|c|c|}
\hline \multicolumn{2}{|c|}{ Year 2000 Objective } & $\begin{array}{l}\text { North } \\
\text { Baseline } \\
\text { Data* }\end{array}$ & $\begin{array}{l}\text { arolina } \\
\text { Current } \\
\text { Data } * *\end{array}$ & $\begin{array}{l}\text { National } \\
\text { Year } 2000 \\
\text { Goal }\end{array}$ & $\begin{array}{c}\text { North Carolina's } \\
\text { Progress }\end{array}$ \\
\hline \multicolumn{6}{|c|}{ PHYSICAL ACTIVITY AND FITNESS } \\
\hline 1.4 & $\begin{array}{l}\text { Increase to at least } 20 \text { percent the proportion } \\
\text { of people aged } 18 \text { and older who engage in } \\
\text { vigorous physical activity that promotes the } \\
\text { development and maintenance of cardio- } \\
\text { respiratory fitness three or more days per } \\
\text { week for } 20 \text { or more minutes per occasion. }\end{array}$ & $\begin{array}{c}6.8 \\
(1994)\end{array}$ & 9.3 & 20.0 & Right direction \\
\hline $1.4 \mathrm{~b}$ & $\begin{array}{l}\text { Increase to at least } 17 \text { percent the proportion } \\
\text { of blacks aged } 18 \text { and older who engage in } \\
\text { vigorous physical activity that promotes the } \\
\text { development and maintenance of cardio- } \\
\text { respiratory fitness three or more days per } \\
\text { week for } 20 \text { or more minutes per occasion. }\end{array}$ & $\begin{array}{c}3.3 \\
(1994)\end{array}$ & 6.2 & 17.0 & Right direction \\
\hline 1.5 & $\begin{array}{l}\text { Reduce to no more than } 15 \text { percent the } \\
\text { proportion of people aged } 6 \text { and older } \\
\text { who engage in no leisure-time physical } \\
\text { activity. (NC uses } 18+\text { ) }\end{array}$ & $\begin{array}{c}40.3 \\
(1994)\end{array}$ & 42.8 & 15.0 & Wrong direction \\
\hline $1.5 \mathrm{a}$ & $\begin{array}{l}\text { Reduce to no more than } 22 \text { percent the } \\
\text { proportion of people aged } 65 \text { and older who } \\
\text { engage in no leisure-time physical activity. }\end{array}$ & $\begin{array}{c}50.6 \\
(1994)\end{array}$ & 58.6 & 22.0 & Wrong direction \\
\hline $1.5 \mathrm{~d}$ & $\begin{array}{l}\text { Reduce to no more than } 20 \text { percent the } \\
\text { proportion of blacks aged } 18 \text { and older who } \\
\text { engage in no leisure-time physical activity. }\end{array}$ & $\begin{array}{c}50.5 \\
(1994)\end{array}$ & 56.9 & 20.0 & Wrong direction \\
\hline \multicolumn{6}{|c|}{ NUTRITION } \\
\hline 2.3 & $\begin{array}{l}\text { Reduce overweight to a prevalence of no } \\
\text { more than } 20 \text { percent among people aged } 20 \\
\text { and older. }\end{array}$ & 25.2 & 29.3 & 20.0 & Wrong direction \\
\hline $2.3 \mathrm{a}$ & $\begin{array}{l}\text { Reduce overweight to a prevalence of no } \\
\text { more than } 25 \text { percent among low-income } \\
\text { women }(<\$ 20,000) \text { aged } 20 \text { and older. }\end{array}$ & 32.6 & 36.7 & 25.0 & Wrong direction \\
\hline $2.3 \mathrm{~b}$ & $\begin{array}{l}\text { Reduce overweight to a prevalence of no } \\
\text { more than } 30 \text { percent among black women } \\
\text { aged } 20 \text { and older. }\end{array}$ & 41.9 & 44.0 & 30.0 & Wrong direction \\
\hline 21.2 & $\begin{array}{l}\text { Increase to at least } 75 \text { percent the proportion } \\
\text { of people aged } 18 \text { and older who have ever } \\
\text { had their cholesterol checked. }\end{array}$ & 64.8 & 68.5 & 75.0 & Right direction \\
\hline 21.2 & $\begin{array}{l}\text { Increase to at least } 75 \text { percent the proportion } \\
\text { of people aged } 18 \text { and older who have had } \\
\text { their cholesterol checked in the last five years. }\end{array}$ & 63.9 & 65.1 & 75.0 & Right direction \\
\hline \multicolumn{6}{|c|}{ TOBACCO } \\
\hline 3.4 & $\begin{array}{l}\text { Reduce cigarette smoking to a prevalence of } \\
\text { no more than } 15 \text { percent among people aged } \\
18 \text { and older. }\end{array}$ & 28.5 & 25.8 & 15.0 & Right direction \\
\hline
\end{tabular}

* 1990 unless otherwise stated.

** 1995 unless otherwise stated. 


\section{Appendix A (continued)}

\begin{tabular}{|c|c|c|c|c|c|}
\hline \multicolumn{2}{|c|}{ Year 2000 Objective } & $\begin{array}{l}\text { North } \\
\text { Baseline } \\
\text { Data* }\end{array}$ & $\begin{array}{l}\text { arolina } \\
\text { Current } \\
\text { Data** }\end{array}$ & $\begin{array}{l}\text { National } \\
\text { Year } 2000 \\
\text { Goal } \\
\end{array}$ & $\begin{array}{l}\text { North Carolina's } \\
\text { Progress }\end{array}$ \\
\hline \multicolumn{6}{|c|}{ TOBACCO (continued) } \\
\hline 3.6 & $\begin{array}{l}\text { Increase to at least } 50 \text { percent the proportion } \\
\text { of cigarette smokers aged } 18 \text { and older who } \\
\text { stopped smoking cigarettes for at least one } \\
\text { day during the preceding year. }\end{array}$ & $\begin{array}{c}42.9 \\
(1994)\end{array}$ & 48.3 & 50.0 & Right direction \\
\hline 3.20 & $\begin{array}{l}\text { Reduce the proportion of young people aged } \\
12-17 \text { who have used cigarettes in the past } \\
\text { month. }\end{array}$ & 32.0 & 31.0 & 6.0 & Right direction \\
\hline \multicolumn{6}{|c|}{ SUBSTANCE ABUSE: ALCOHOL AND OTHER DRUGS } \\
\hline 4.2 & $\begin{array}{l}\text { Reduce cirrhosis deaths to no more than } \\
6 \text { per } 100,000 \text { people. }\end{array}$ & 9.0 & 7.5 & 6.0 & Right direction \\
\hline 4.3 & $\begin{array}{l}\text { Reduce drug-related deaths to no more than } \\
3 \text { per } 100,000 \text { people. }\end{array}$ & 2.9 & 3.2 & 3.0 & Wrong direction \\
\hline 4.6 & $\begin{array}{l}\text { Reduce the proportion of young people aged } \\
12-17 \text { who have used alcohol in the past } \\
\text { month. }\end{array}$ & 35.0 & 39.7 & 12.6 & Wrong direction \\
\hline 4.6 & $\begin{array}{l}\text { Reduce the proportion of young people aged } \\
12-17 \text { who have used marijuana in the past } \\
\text { month. }\end{array}$ & 16.0 & 21.7 & 3.2 & Wrong direction \\
\hline \multicolumn{6}{|c|}{ FAMILY PLANNING } \\
\hline & $\begin{array}{l}\text { Reduce pregnancies among females aged } \\
15-17 \text { to no more than } 50 \text { per } 1,000 \text { adolescents. }\end{array}$ & 71.7 & 65.1 & 50.0 & Right direction \\
\hline & $\begin{array}{l}\text { Reduce pregnancies among black adolescent } \\
\text { females aged } 15-19 \text { to no more than } 120 \text { per } \\
1000 \text {. }\end{array}$ & 154.9 & - & 120.0 & Data not available \\
\hline \multicolumn{6}{|c|}{ MENTAL HEALTH AND MENTAL DISORDERS } \\
\hline 6.1 & $\begin{array}{l}\text { Reduce suicides to no more than } 10.5 \text { per } \\
100,000 \text { people. }\end{array}$ & 12.9 & 11.5 & 10.5 & Right direction \\
\hline $6.1 \mathrm{a}$ & $\begin{array}{l}\text { Reduce suicides among youth aged } 15-19 \\
\text { to no more than } 8.2 \text { per } 100,000 \text {. }\end{array}$ & 10.5 & 13.8 & 8.2 & Wrong direction \\
\hline \multicolumn{6}{|c|}{ VIOLENT AND ABUSIVE BEHAVIOR } \\
\hline 7.1 & $\begin{array}{l}\text { Reduce homicides to no more than } 7.2 \text { per } \\
100,000 \text { people. }\end{array}$ & 11.4 & 9.7 & 7.2 & Right direction \\
\hline & $\begin{array}{l}\text { Reduce homicides among black men aged } \\
15-34 \text { to no more than } 72.4 \text { per } 100,000 \text {. }\end{array}$ & 79.9 & - & 72.4 & Data not available \\
\hline \multicolumn{6}{|c|}{ UNINTENTIONAL INJURIES } \\
\hline 9.1 & $\begin{array}{l}\text { Reduce deaths caused by unintentional } \\
\text { injuries to no more than } 29.3 \text { per } 100,000 \text { people. }\end{array}$ & 38.0 & 35.0 & 29.3 & Right direction \\
\hline & $\begin{array}{l}\text { Reduce nonfatal unintentional injuries so } \\
\text { that hospitalizations for this condition are } \\
\text { no more than } 754 \text { per } 100,000 \text { people. }\end{array}$ & $\begin{array}{c}885.6 \\
(1993)\end{array}$ & 819.5 & 754.0 & Right direction \\
\hline
\end{tabular}

* 1990 unless otherwise stated.

** 1995 unless otherwise stated. 
Appendix A (continued)

\begin{tabular}{|c|c|c|c|c|}
\hline Year 2000 Objective & $\begin{array}{l}\text { North } \\
\text { Baseline } \\
\text { Data* }\end{array}$ & $\begin{array}{l}\text { arolina } \\
\text { Current } \\
\text { Data** }\end{array}$ & $\begin{array}{l}\text { National } \\
\text { Year 2000 } \\
\text { Goal } \\
\end{array}$ & $\begin{array}{c}\text { North Carolina's } \\
\text { Progress }\end{array}$ \\
\hline \multicolumn{5}{|l|}{ UNINTENTIONAL INJURIES (continued) } \\
\hline $\begin{array}{l}9.3 \text { Reduce deaths caused by motor vehicle } \\
\text { crashes to no more than } 14.2 \text { per } 100,000 \\
\text { people. }\end{array}$ & 21.2 & 20.2 & 14.2 & Right direction \\
\hline $\begin{array}{l}\text { 9.7 Reduce hip fractures among people aged } 65 \\
\text { and older so that hospitalizations for this } \\
\text { condition are no more than } 607 \text { per } \\
100,000 \text { people. }\end{array}$ & $\begin{array}{r}712.4 \\
(1993)\end{array}$ & 735.4 & 607.0 & Wrong direction \\
\hline $\begin{array}{l}9.9 \text { Reduce nonfatal head injuries so that } \\
\text { hospitalizations for this condition are no } \\
\text { more than } 106 \text { per } 100,000 \text { people. }\end{array}$ & $\begin{array}{c}97.3 \\
(1993)\end{array}$ & 80.4 & 106.0 & Goal achieved \\
\hline \multicolumn{5}{|l|}{ OCCUPATIONAL SAFETY AND HEALTH } \\
\hline $\begin{array}{l}\text { 10.1 Reduce deaths from work-related injuries to } \\
\text { no more than } 4 \text { per } 100,000 \text { full-time workers. }\end{array}$ & $\begin{array}{c}5.3 \\
(1992)\end{array}$ & $\begin{array}{c}6.6 \\
(1994)\end{array}$ & 4.0 & Wrong direction \\
\hline $\begin{array}{l}\text { 10.1b Reduce deaths among construction workers } \\
\text { from work-related injuries to no more than } \\
17 \text { per } 100,000 \text { full-time workers. }\end{array}$ & $\begin{array}{c}10.7 \\
(1992)\end{array}$ & $\begin{array}{c}13.4 \\
(1994)\end{array}$ & 17.0 & Goal achieved \\
\hline $\begin{array}{l}\text { 10.1c Reduce deaths among transportation workers } \\
\text { from work-related injuries to no more than } \\
10 \text { per } 100,000 \text { full-time workers. }\end{array}$ & $\begin{array}{c}15.7 \\
(1992)\end{array}$ & $\begin{array}{c}21.9 \\
(1994)\end{array}$ & 10.0 & Wrong direction \\
\hline $\begin{array}{l}10.1 \mathrm{~d} \text { Reduce deaths among farm workers from } \\
\text { work-related injuries to no more than } 9.5 \text { per } \\
100,000 \text { full-time workers. }\end{array}$ & $\begin{array}{c}25.8 \\
(1992)\end{array}$ & $\begin{array}{c}18.8 \\
(1994)\end{array}$ & 9.5 & Right direction \\
\hline $\begin{array}{l}\text { 10.2a Reduce work-related injuries among } \\
\text { construction workers resulting in medical } \\
\text { treatment, lost time from work, or restricted- } \\
\text { work activity to no more than } 10 \text { cases per } \\
100 \text { full-time workers. }\end{array}$ & $\begin{array}{c}11.9 \\
(1994)\end{array}$ & 10.1 & 10.0 & Right direction \\
\hline $\begin{array}{l}\text { 10.2c Reduce work-related injuries among } \\
\text { farm workers resulting in medical } \\
\text { treatment, lost time from work, or restricted- } \\
\text { work activity to no more than } 8 \text { cases per } \\
100 \text { full-time workers. }\end{array}$ & $\begin{array}{c}8.5 \\
(1994)\end{array}$ & 10.2 & 8.0 & Wrong direction \\
\hline $\begin{array}{l}10.2 \mathrm{~d} \text { Reduce work-related injuries among } \\
\text { transportation workers resulting in medical } \\
\text { treatment, lost time from work, or restricted- } \\
\text { work activity to no more than } 6 \text { cases per } \\
100 \text { full-time workers. }\end{array}$ & $\begin{array}{c}8.8 \\
(1994)\end{array}$ & 7.8 & 6.0 & Right direction \\
\hline \multicolumn{5}{|l|}{ ENVIRONMENTAL HEALTH } \\
\hline $\begin{array}{l}11.1 \text { Reduce asthma morbidity, as measured by } \\
\text { a reduction in asthma hospitalizations to no } \\
\text { more than } 160 \text { per } 100,000 \text { people. }\end{array}$ & $\begin{array}{c}141.8 \\
(1993)\end{array}$ & 147.8 & 160.0 & Goal achieved \\
\hline
\end{tabular}




\section{Appendix A (continued)}

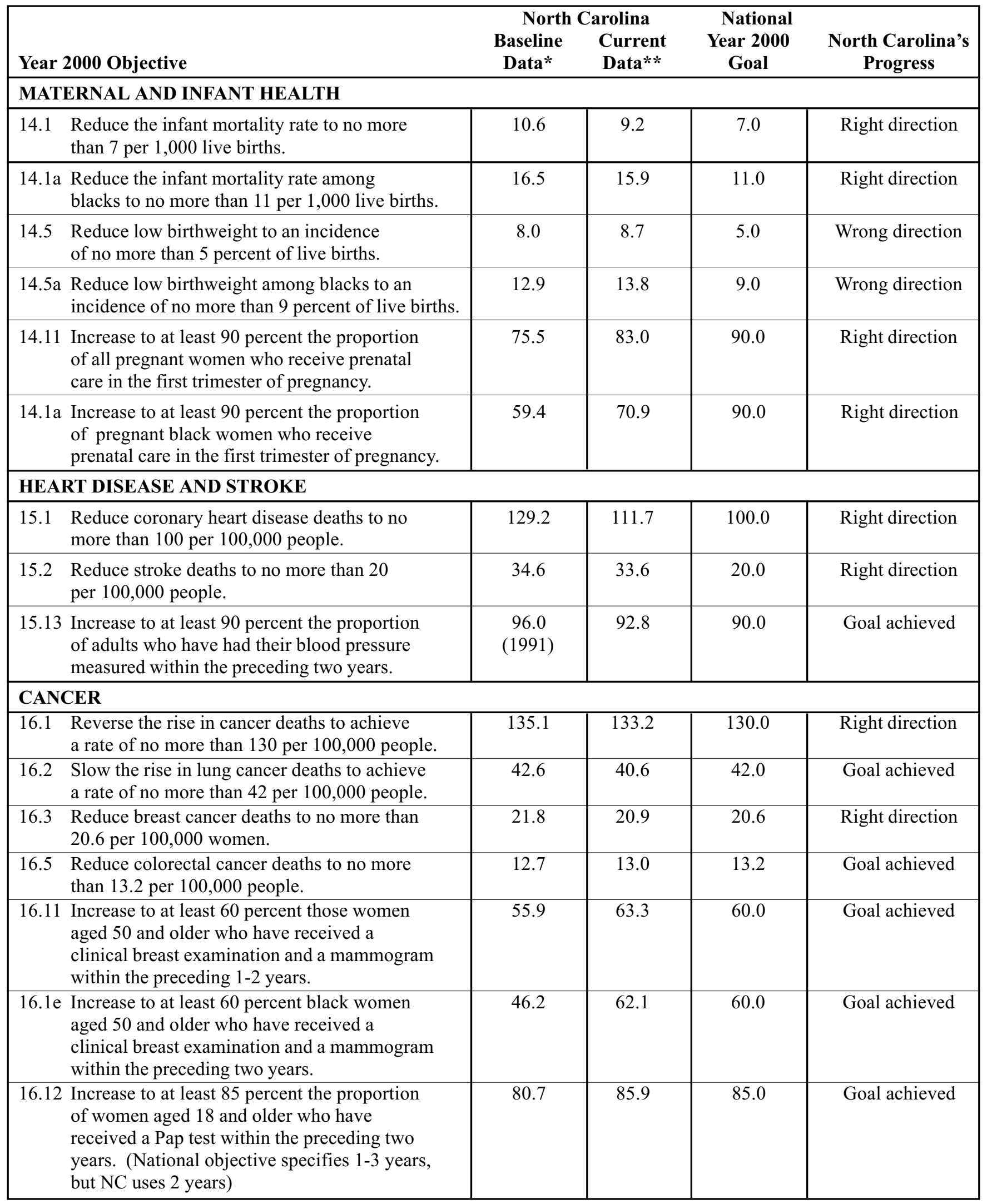

* 1990 unless otherwise stated.

** 1995 unless otherwise stated. 
Appendix A (continued)

\begin{tabular}{|c|c|c|c|c|c|}
\hline \multicolumn{2}{|c|}{ Year 2000 Objective } & $\begin{array}{l}\text { North } \\
\text { Baseline } \\
\text { Data* }\end{array}$ & $\begin{array}{l}\text { arolina } \\
\text { Current } \\
\text { Data** }\end{array}$ & $\begin{array}{l}\text { National } \\
\text { Year 2000 } \\
\text { Goal } \\
\end{array}$ & $\begin{array}{l}\text { North Carolina's } \\
\text { Progress }\end{array}$ \\
\hline \multicolumn{6}{|c|}{ DIABETES AND CHRONIC DISABLING CONDITIONS } \\
\hline & $\begin{array}{l}\text { Reduce diabetes-related deaths to no more } \\
\text { than } 34 \text { per } 100,000 .\end{array}$ & 45.6 & 48.4 & 34.0 & Wrong direction \\
\hline 17.11 & $\begin{array}{l}\text { Reduce diabetes to a prevalence of no more } \\
\text { than } 25 \text { per } 1,000 \text { people }\end{array}$ & 59.0 & 45.0 & 25.0 & Right direction \\
\hline $17.1 \mathrm{e}$ & $\begin{array}{l}\text { Reduce diabetes among blacks to a prevalence } \\
\text { of no more than } 32 \text { per } 1,000 .\end{array}$ & 87.0 & 72.0 & 32.0 & Right direction \\
\hline \multicolumn{6}{|c|}{ HIV INFECTION } \\
\hline 18.1 & $\begin{array}{l}\text { Confine annual incidence of diagnosed AIDS } \\
\text { cases to no more than } 43 \text { per } 100,000 \text { population. }\end{array}$ & 8.0 & 11.1 & 43.0 & Goal achieved \\
\hline \multicolumn{6}{|c|}{ SEXUALLY TRANSMITTED DISEASES } \\
\hline & $\begin{array}{l}\text { Reduce gonorrhea to an incidence of no more } \\
\text { than } 100 \text { cases per } 100,000 \text { people. }\end{array}$ & 501.8 & 333.0 & 100.0 & Right direction \\
\hline $19.1 \mathrm{a}$ & $\begin{array}{l}\text { Reduce gonorrhea among blacks to an incidence } \\
\text { of no more than } 650 \text { cases per } 100,000\end{array}$ & 2046.9 & - & 650.0 & Data not available \\
\hline 19.3 & $\begin{array}{l}\text { Reduce primary and secondary syphilis to an } \\
\text { incidence of no more than } 4 \text { cases per } 100,000 \\
\text { people. }\end{array}$ & 26.4 & 15.7 & 4.0 & Right direction \\
\hline $19.3 \mathrm{a}$ & $\begin{array}{l}\text { Reduce primary and secondary syphilis among } \\
\text { blacks to an incidence of no more than } 30 \\
\text { cases per } 100,000 \text {. }\end{array}$ & 108.8 & - & 30.0 & Data not available \\
\hline \multicolumn{6}{|c|}{ IMMUNIZATION AND INFECTIOUS DISEASES } \\
\hline & $\begin{array}{l}\text { Reduce tuberculosis to an incidence of no } \\
\text { more than } 3.5 \text { cases per } 100,000 \text { people. }\end{array}$ & 10.0 & 7.2 & 3.5 & Right direction \\
\hline 20.11 & $\begin{array}{l}\text { Increase immunization levels among children } \\
\text { in licensed child care facilities and } \\
\text { kindergarten } \\
\text { to at least } 95 \text { percent. }\end{array}$ & $\begin{array}{c}93.0 \\
95.0 \\
(1994 / 1995) \\
\end{array}$ & $\begin{array}{l}90.5 \\
98.3\end{array}$ & $\begin{array}{l}95.0 \\
95.0\end{array}$ & $\begin{array}{l}\text { Wrong direction } \\
\text { Goal achieved }\end{array}$ \\
\hline 21.2 & $\begin{array}{l}\text { Increase to at least } 60 \text { percent the proportion } \\
\text { of people aged } 65 \text { and older who have received } \\
\text { an influenza vaccine in the last year. }\end{array}$ & $\begin{array}{c}50.9 \\
(1993)\end{array}$ & 52.2 & 60.0 & Right direction \\
\hline 21.2 & $\begin{array}{l}\text { Increase to at least } 60 \text { percent the proportion } \\
\text { of people aged } 65 \text { and older who have received } \\
\text { pneumococcal vaccine in their lifetime. }\end{array}$ & $\begin{array}{c}26.3 \\
(1993)\end{array}$ & 30.7 & 60.0 & Right direction \\
\hline \multicolumn{6}{|c|}{ CLINICAL PREVENTIVE SERVICES } \\
\hline & $\begin{array}{l}\text { Increase to at least } 91 \text { percent the proportion } \\
\text { of people who received a routine check-up in } \\
\text { the last two years. (National objective specifies } \\
3 \text { years, but NC uses } 2 \text { years) }\end{array}$ & $\begin{array}{c}84.3 \\
(1993)\end{array}$ & 82.6 & 91.0 & Wrong direction \\
\hline & $\begin{array}{l}\text { Increase to at least } 95 \text { percent the proportion } \\
\text { of people who have a specific source of } \\
\text { ongoing primary care for coordination of their } \\
\text { preventive and episodic health care. }\end{array}$ & $\begin{array}{c}80.5 \\
(1994)\end{array}$ & - & 95.0 & Data not available \\
\hline
\end{tabular}




\section{Appendix A (continued)}

\begin{tabular}{|l|c|c|c|c|}
\hline \multicolumn{2}{|c|}{$\begin{array}{c}\text { North Carolina } \\
\text { Baseline } \\
\text { Data* }\end{array}$} & $\begin{array}{c}\text { National } \\
\text { Data** }\end{array}$ & $\begin{array}{c}\text { Year 2000 } \\
\text { Goal }\end{array}$ & $\begin{array}{c}\text { North Carolina's } \\
\text { Progress }\end{array}$ \\
\hline CLINICAL PREVENTIVE SERVICES (continued) & \multicolumn{2}{|c|}{} & & Data not available \\
\hline $\begin{array}{l}\text { 21.3b Increase to at least 95 percent the proportion } \\
\text { of blacks who have a specific source of ongoing } \\
\text { primary care for coordination of their preventive } \\
\text { and episodic health care. }\end{array}$ & $\begin{array}{c}78.0 \\
(1994)\end{array}$ & - & 05.0 & Data not available \\
\hline $21.4 \begin{array}{l}\text { Decrease to 0 percent the proportion of } \\
\text { people under 65 years without health care } \\
\text { coverage. }\end{array}$ & $\begin{array}{c}10.8 \\
(1994)\end{array}$ & - & 0.0 & Data not available \\
\hline $\begin{array}{l}21.4 c \text { Decrease to 0 percent the proportion of } \\
\text { blacks under 65 years without health care } \\
\text { coverage. }\end{array}$ & $\begin{array}{c}13.8 \\
(1994)\end{array}$ & - & & \\
\hline
\end{tabular}

* 1990 unless otherwise stated.

** 1995 unless otherwise stated. 
Department of Environment, Health, and Natural Resources

State Center for Health Statistics

P. O. Box 29538

Raleigh, NC 27626-0538

919/733-4728 